Elsevier Editorial System(tm) for Quaternary Science Reviews

Manuscript Draft

Manuscript Number:

Title: Glacial to Holocene climate changes in the SE Pacific. The Raraku Lake sedimentary record (Easter Island, $\left.27^{\circ} \mathrm{S}\right)$.

Article Type: Research and Review Paper

Corresponding Author: Dr. Alberto Saez, Dr.

Corresponding Author's Institution: University of Barcelona

First Author: Alberto Saez, Dr.

Order of Authors: Alberto Saez, Dr.; Blas L Valero-Garcés, Dr.; Santiago Giralt, Dr.; Ana Moreno, Dr.; Roberto Bao, Dr.; Juan J Pueyo, Dr.; Juan J Pueyo, Dr.; Armand Hernández

Abstract: Easter Island (SE Pacific, $27^{\circ} \mathrm{S}$ ) provides a unique opportunity to reconstruct past climate changes in the South Pacific region based on terrestrial archives. Climates in the mid- to lowlatitude region of the eastern South Pacific Ocean are controlled by fluctuations in the Westerlies winds, the South Pacific Convergence Zone and the South Pacific Anticyclone. Here we present a high-resolution reconstruction of lake dynamics, watershed processes and paleohydrology for the last 34000 years based on a sedimentological and geochemical multiproxy study of 8 cores from the Raraku Lake sediments constrained by 22 AMS radiocarbon dates. This multicore strategy has reconstructed the sedimentary architecture of the lake infilling and provided a stratigraphic framework to integrate and correlate previous core and vegetation studies conducted in the lake. High lake levels and clastic input dominated sedimentation in Raraku Lake between 34 to $28 \mathrm{cal}$ kyr BP. Sedimentological and geochemical evidences support previously reported pollen data showing a relatively open forest in the watershed during the Glacial period and a cold and relatively humid climate. Between 28 and 17.3 cal kyr BP, including the LGM period, colder conditions contributed to a reduction of the tree coverage in the island. The end of Glacial Period occurred at 17.3 cal kyr BP and was characterized by a sharp decrease in lake level conducive to the 
development of major floods due to the erosion of littoral sediments. Deglaciation (Termination 1) between 17.3 and 12.5 cal kyr BP was characterized by an increase in lake productivity, a decrease in the terrigenous input and a rapid lake level recovery inaugurating a period of intermediate lake levels, dominance of organic deposition and algal lamination. The timing and duration of deglaciation events in Easter Island broadly agree with other mid- and low latitude circum South Pacific terrestrial records. The transition to the Holocene was characterized by lower lake levels. The lake level dropped during the early Holocene (ca. $9.5 \mathrm{cal}$ kyr BP) and peatbog and shallow lake conditions dominated till mid Holocene, partially favored by the colmatation of the lacustrine basin. During the mid to late Holocene drought phases led to periods of persistent low water table, subaerial exposure and erosion, generating a sedimentary hiatus in the Raraku sequence, from 4.2 to $0.8 \mathrm{cal} \mathrm{kyr} \mathrm{BP}$. The human colonization of the island coincides with a new humid episode that started $800 \mathrm{yrs}$ ago. The palm deforestation of the Easter Island, attributed to the human impact could have started earlier, during the 4.2 to 0.8 cal kyr BP sedimentary gap. Changes in land uses (farming, intensive cattle) during the last century had a large impact in the hydrology and limnology (eutrophication) of the lake. 
Dear Editor,

Barcelona, $17^{\text {th }}$ February 2009

The main aim of the manuscript that we are submitting to Quaternary Science Reviews is to provide new insights about the environmental and climate evolution of Easter Island during the last 34000 cal years BP. We have achieved this aim through the high resolution study of new eight cores recovered in March 2006 at Lake Raraku and constrained by 22 AMS radiocarbon dates. This is the first time that a multicore strategy coupled with sedimentological, mineralogical and geochemical techniques are applied to Raraku Lake. As a result, we have been able to reconstruct the architecture of the lake sedimentary infilling and the limnological evolution of the lake. The reconstructed changes in terrigenous input, lake productivity, and lake level changes from Last Glacial to the present have been integrated with previous studies and the available pollen records to provide a paleoclimate reconstruction of the mid- to low-latitude southeastern Pacific region. The timing and characteristics of the main temperature and moisture changes in Easter Island show similarities with other terrestrial and marine records located in the south circum Pacific region. Moreover, our research provides new data on the impact in the lake ecosystem of human activities (deforestation and intensive cattle farming) during the last centuries.

We suggest following reviewers because they are the main specialists in the topic of the manuscript:

Mark Abbott

Geology and Planetary Science

University of Pittsburgh

4107 O'Hara Street

Room 200 SRCC Building

Pittsburgh, PA 15260-3332 USA

email: mabbott1@pitt.edu

Sherilyn Fritz

University of Nebraska

301 Bessey Hall 402-472-6431

email: sfritz2@unl.edu

Herbert E. Wright

Limnological Research Center

University of Minnesota

Office: 221 Pillsbury Hall

email: hew@umn.edu

Professor John Flenley

Massey University, New Zealand

email: J.Flenley@,Massey.ac.nz

Sincerely yours, The authors 



\title{
Glacial to Holocene climate changes in the SE Pacific. The Raraku Lake sedimentary record (Easter Island, $\mathbf{2 7}^{\circ} \mathrm{S}$ )
}

\author{
Alberto Sáez ${ }^{1 *}$, Blas L.Valero-Garcés ${ }^{2}$, Santiago Giralt ${ }^{3}$, Ana Moreno $^{2}$, \\ Roberto Bao ${ }^{4}$, Juan J. Pueyo ${ }^{1}$, Armand Hernández ${ }^{3}$, David Casas ${ }^{5}$ \\ ${ }^{1}$ Facultat de Geologia, Universitat de Barcelona, c/ Martí Franqués s/n, E-08028 Barcelona (Spain) \\ ${ }^{2}$ Instituto Pirenaico de Ecología CSIC. Apdo. 13034, E-50080 Zaragoza (Spain) \\ ${ }^{3}$ Instituto de Ciencias de la Tierra 'Jaume Almera' - CSIC, c/ Lluís Sole Sabaris s/n, E-08028 Barcelona (Spain) \\ ${ }^{4}$ Facultade de Ciencias, Universidade da Coruña, Campus da Zapateira s/n, E-15071 A Coruña (Spain) \\ ${ }^{5}$ Institut de Ciències del Mar- CSIC, Passeig Marítim de la Barceloneta, 37. E-08003 Barcelona (Spain) \\ (*) corresponding author (a.saez@,ub.edu)
}

\begin{abstract}
Easter Island (SE Pacific, $27^{\circ} \mathrm{S}$ ) provides a unique opportunity to reconstruct past climate changes in the South Pacific region based on terrestrial archives. Climates in the mid- to low-latitude region of the eastern South Pacific Ocean are controlled by fluctuations in the Westerlies winds, the South Pacific Convergence Zone and the South Pacific Anticyclone. Here we present a high-resolution reconstruction of lake dynamics, watershed processes and paleohydrology for the last 34000 cal. years BP based on a sedimentological and geochemical multiproxy study of 8 cores from the Raraku Lake sediments constrained by 22 AMS radiocarbon dates. This multicore strategy has reconstructed the sedimentary architecture of the lake infilling and provided a stratigraphic framework to integrate and correlate previous core and vegetation studies conducted in the lake. High lake levels and clastic input dominated sedimentation in Raraku Lake between 34 to 28 cal kyr BP. Sedimentological and geochemical evidences support previously reported pollen data showing a relatively open forest in the watershed during the Glacial period and a cold and relatively humid climate. Between 28 and 17.3 cal kyr BP, including the LGM period, colder conditions contributed to a reduction of the tree coverage in the island. The end of Glacial Period occurred at 17.3 cal kyr BP and was characterized by a sharp decrease in lake level conducive to the development of major floods due to the erosion of littoral sediments. Deglaciation (Termination 1) between 17.3 and 12.5 cal kyr BP was characterized by an increase in lake productivity, a decrease in the terrigenous input and a rapid lake level recovery inaugurating a period of intermediate lake levels, dominance of organic deposition and algal lamination. The timing and duration of deglaciation events in Easter Island broadly agree with other mid- and low latitude circum South Pacific terrestrial records. The transition to the Holocene was characterized by lower lake levels. The lake level dropped during the early Holocene (ca. 9.5 cal kyr BP) and peatbog and shallow lake conditions dominated till mid Holocene, partially favored by the colmatation of the lacustrine basin. During the mid to late Holocene drought phases led to periods of persistent low water table, subaerial exposure and erosion, generating a sedimentary hiatus in the Raraku sequence, from 4.2 to 0.8 cal
\end{abstract}


kyr BP. The human colonization of the island coincides with a new humid episode that started 800 yrs ago. The palm deforestation of the Easter Island, attributed to the human impact could have started earlier, during the 4.2 to 0.8 cal kyr BP sedimentary gap. Changes in land uses (farming, intensive cattle) during the last century had a large impact in the hydrology and limnology (eutrophication) of the lake .

keywords: Rapa Nui, Glacial, Last Glacial Maximum, Termination 1, Holocene, deforestation 


\section{Introduction}

Lacustrine sediments from Easter Island $\left(27^{\circ} \mathrm{S}\right)$ are the only terrestrial records that can provide climate reconstructions for the Late Pleistocene and Holocene in the mid- to low-latitude region of the eastern South Pacific Ocean. Easter Island is located thousands of kilometers far from continental sites with potentially comparable paleoclimatic records, including New Zealand (McGlone, 2002; Newnham et al., 2003; Vandergoes et al., 2005, among others), mid latitudes of the Andes (Moreno and León 2003; Valero-Garcés et al., 2005; Maldonado and Villagrán, 2006; Heusser and Heusser, 2006; Markgraf et al., 2007; Haberzettl et al., 2007; Bertrand, et al., 2008, among others), and low latitudes of the Andes (Paduano et al., 2003; Tapia et al 2003; Latorre et al., 2006; Giralt et al., 2008). Marine records are available in mid (Lamy et al., 2007) and low latitudes (Lea et al., 2006; Pena et al., 2008) of South America and in the southern Pacific (ODP sites 1233, and 1240, GeoB site 7139, and TR site 162-22) but not close to Easter Island (Fig. 1). Climate of Easter Island is controlled by large scale atmospheric and oceanic patterns, and it is not biased by the continental effects on local convection as circum Pacific sites. The location of Easter Island in the subtropical latitudes, close to the northernmost limit of the Southern Hemisphere (SH) westerly winds, is suitable to reflect the timing and nature of the major oceanographic and atmospheric changes affecting the southeast Pacific and the fluctuations of the South Pacific Convergence Zone (SPCZ) during the last glacial cycle. Particularly, the Easter Island lacustrine sequences can provide new insights on both the dynamics of the shifting westerlies and the SPCZ during the glacial-interglacial transition (Lamy et al., 1998; Valero-Garcés et al., 2005), and the Holocene (Jenny et al., 2002; Latorre et al., 2006). They could also help to understand the large scale controls on precipitation in tropical and extratropical regions, and the connections between marine variability and the hydrological response in the continents (Kaiser et al., 2008).

More marine and terrestrial records are needed (1) to identify the earlier timing of the deglaciation onset in the SH indicated by ice cores and marine records (Stott et al., 2007), and (2) to understand the nature of the Northern Hemisphere (NH) abrupt climate events (eg. Heinrich events) in the southern Hemisphere (Baker et al., 2001; Kaiser et al., 2008). A strong influence of summer insolation changes in the South American climate has been documented through the influence in the summer monsoon (Cruz et al., 2005) and the westerlies location and intensity during the glacial/interglacial transition and the Holocene in terrestrial (Jenny et al., 2002; Valero-Garcés et al., 2005; Moreno et al., 2007) and marine records (Lamy et al., 2001; Stuut et al., 2004).

The palaeoenvironmental record of Easter Island may contribute to a better understanding of the relative influence of high and low latitude dynamics as drivers of climate change during glacial and interglacial periods. The sedimentary records of the Easter Island lakes have previously been studied mostly using biological indicators (pollen, diatoms) in littoral cores (Flenley and King, 1984; Flenley et al., 1991; Dumont et al., 1998). These studies focused on the deforestation, traditionally related to the human occupation of the island during the last millennium. Low resolution 
pollen studies have also described the late Quaternary paleoclimatic changes (Flenley et al., 1991; Azizi and Flenley, 2008). The main aim of this paper is to provide new insights about the environmental and climate evolution of Easter Island during the last 34000 cal years BP through a high resolution study of new eight cores recovered in March 2006 at Raraku Lake. This is the first time a multicore strategy coupled with sedimentological, mineralogical and geochemical techniques are applied to Raraku Lake. As a result, we have been able to reconstruct the architecture of the lake sedimentary infilling and the limnological evolution of the lake. The reconstructed changes in terrigenous input, lake productivity, and lake level changes from last glacial to the present have been integrated with previous studies and the available pollen records to provide a paleoclimate reconstruction of the mid- to low-latitude southeastern Pacific region. The timing and characteristics of the main temperature and humidity changes in Easter Island show similarities with other terrestrial and marine records located in the south circum Pacific region. Moreover, our research provides new data on the impact in the lake ecosystem of human activities (deforestation and intensive cattle farming) during the last centuries.

\section{Geological and climatic setting}

The Raraku Lake (Easter Island, $27^{\circ} 07^{\prime} \mathrm{S}, 1^{109^{\circ}} 22^{\prime} \mathrm{W}$, about $70 \mathrm{~m}$ a.s.1.), located in a Miocene volcano crater, has a surface of $0.11 \mathrm{~km}^{2}$ and in 2006 it had $3 \mathrm{~m}$ of maximum water depth. The crater catchment has a surface area of 0.35 $\mathrm{km}^{2}$ and it is composed by volcanic tuffs (traqui-basaltic hyaloclastites), rich in glass, feldspars and ilmenite. (González-Ferrán et al., 2004). The lake is topographically and hydrologically closed, with no surface outlet, although water is pumped out of the lake for human consumption and irrigation. Rainfall and run-off are the only water inputs. Groundwater losses have not been quantified, but hydrogeological studies demonstrate that the water body of Raraku Lake is placed several tens of meters above the local water table and disconnected of the main island aquifer (Herrera and Custodio, 2008). Lake waters are acidic ( $\mathrm{pH}$ around 6.3), dilute (average conductivity is $640 \mathrm{mS} \mathrm{cm-}{ }^{1}$, Geller, 1992) and of $\mathrm{Cl}-\mathrm{HCO}_{3}$-Na type. The waters are turbid and well mixed (surface and bottom temperatures in March 2006 were $25.69{ }^{\circ} \mathrm{C}$ and $25.11{ }^{\circ} \mathrm{C}$ respectively). The lake has a flat - bottom morphology and relatively steep margins and is surrounded by a littoral belt of Scirpus sp. mat, which also form large floating patches that accumulate in the eastern side of the lake due to the prevalent westerly wind.

Easter Island is located within the South Pacific subtropical Gyre and it has a summer season (from October to April) influenced by E-SE Trade Winds and a winter season (from May to September) dominated by N-NW Westerlies winds (Mucciarone and Dunbar, 2003). Temperature varies from $16^{\circ} \mathrm{C}$ (July- September) to $26^{\circ} \mathrm{C}$ (January to March). Average annual rainfall is about $1130 \mathrm{~mm}$ (maximum values in winter months from March to July). Precipitation 
depends on the westward oceanic airmasses crossing the island which are controlled by the interplay of the South Pacific Anticyclone (SPA), centered at $15^{\circ} \mathrm{S}$, the South Pacific Convergence Zone (SPCZ), centered at $45^{\circ} \mathrm{S}$, and the westerly storm tracks, centered at $34^{\circ} \mathrm{S}$ (Fig. 1). The interaction between these three large systems determines the climate on the Easter Island at different time scales. Seasonally, the weakening and northward migration of SPA during fall and winter causes an increase in precipitation during the April-June period, allowing the storm fronts associated with the westerlies winds pass over the island. During the summers, SPA is displaced southwards blocking the westerly storm fronts north of $34^{\circ} \mathrm{S}$ (Garreaud and Aceituno, 2002) and areas such as the Easter Island receive minimum precipitation. Interannual-decadal and millennial-scale climate variations in S Pacific region during the Pleistocene and Holocene have been controlled by the SPA and SPCZ fluctuations in location and intensity, driven by changes in the precession- and obliquity-related insolation (Beaufort et al., 2001; Rind et al., 2001; Tudhope et al., 2001; Moy et al., 2002; Koutavas et al., 2002; Stott et al., 2002; Yuan, 2004; Pena et al., 2008).

\section{Methodology}

In March 2006, eight sediment cores (up to $14 \mathrm{~m}$ long) were recovered from Raraku Lake using a UWITEC corer installed in a UWITEC platform raft (cores RAR1 to RAR8). Magnetic susceptibility was measured using a GEOTEK $^{\mathrm{TM}}$ Multi-Sensor Core Logger every centimeter. The sections were split longitudinally, imaged using a digital photograph and logged with detailed sedimentological and lithological descriptions, complemented by smear slides microscopic observations every $5 \mathrm{~cm}$ in all the cores.

The cores were correlated using sedimentary facies, magnetic susceptibility values and key sediment layers. Cores RAR3 and RAR7, located in offshore and marginal zones respectively, were selected for high resolution analyses. A composite sequence was constructed using these two cores in order to have a complete record of the sedimentary infill in the offshore zone of the lake.

XRF (X-Ray Fluorescence) analyses were performed using the new generation XRF ITRAX core scanner from the Large Lakes Observatory (Duluth), University of Minnesota with a spatial resolution of $2 \mathrm{~mm}, 60 \mathrm{~s}$ count time, 30 kV and 20 mA. Although twenty five elements (Mg, Al, Si, P, S, Cl, Ar, K, Ca, Sc, Ti, Ba, Fe; Ni, Cu, Zn, As, Rb, Sr, $\mathrm{Y}, \mathrm{Zr}$, and $\mathrm{Pb}$ ) were determined, only $\mathrm{Si}, \mathrm{Ca}, \mathrm{S}, \mathrm{Fe}$ and $\mathrm{Ti}$ elements had enough intensity (counts per second) to be considered statistically consistent. In addition, the incoherence/coherence (inc/coh) ratio is also presented as a measure of the relation between the incoherent scatter from the Mo tube (Compton scattering - or - inelastic scattering) and the coherent scatter (Raleigh scattering or elastic scattering), i.e. an indicator of the primary radiation from the x-ray tube that is scattered in the sample and thereby affected by the sample composition (Croudace et al., 2006). Comparison with 
TOC analyses shows that this ratio is closely related to the organic matter content of the sample. X-ray radiographs were obtained from core sections by the same XRF core scanner. Samples for X-ray diffraction were taken every $5 \mathrm{~cm}$, dried at $60{ }^{\circ} \mathrm{C}$ for 24 hours, frozen with liquid nitrogen and immediately ground using a ring mill for about 5 seconds. X-ray diffractions were performed using an automatic Siemens D-500 X-ray diffractometer with the following conditions: $\mathrm{Cu} \mathrm{k \alpha}, 40 \mathrm{kV}, 30 \mathrm{~mA}$, and graphite monochromator. The X-ray diffraction patterns revealed that the samples were composed of a minor crystalline fraction and a major amorphous one with a broad peak centered between $20^{\circ}$ and $25^{\circ} 2 \theta$. The identification and quantification of the different mineralogical species present in the crystalline fraction were carried out following a standard procedure (Chung, 1974).

Total Organic (TOC), Total Inorganic (TIC) and Total Carbon (TC) determinations were performed every five centimeters using a UIC model $5011 \mathrm{CO}_{2}$ Coulometer. Samples for Total Sulfur (TS) and Total Nitrogen (TN) were taken every $5 \mathrm{~cm}$ and measured respectively with a LECO SC144 DR furnace (TS) and by a VARIO MAX CN elemental analyzer (TN). Loss of ignition (LOI) values at $450{ }^{\circ} \mathrm{C}$ were also obtained at the same intervals. Samples for diatom analyses were treated according to the method of Renberg (1990). Identification of the taxa was performed with a Nomarski differential interference contrast microscope.

The correlation analysis (r2) and their significance (p-values) was performed over the entire set of proxies using the R software package (R Development Core Team, 2008). The p-values were adjusted by applying the Bonferroni test.

The chronological framework of the sedimentary sequence of Raraku Lake was constructed using 36 radiocarbon AMS dates (Table 1) obtained from pollen-enriched extract and large stem fragments of Scirpus sp. in the Poznan Radiocarbon Laboratory (Poland). Pollen enrichment processes followed the classical chemical treatment of Goeury and de Beaulieu (1979) slightly modified by Burjachs et al. (2003). Microscopic observations were made in the pollen concentrates to assure that samples were dominated by pollen grains and to minimize modern contamination and the presence of amorphous lacustrine matter. The calibration of the radiocarbon dates was performed using the CALIB 5.02 software and the INTCAL98 curve (Reimer et al., 2004) and CalPal (Danzeglocke et al., 2008) for samples older than 20000 radiocarbon years BP. No reservoir effect correction has been applied to the ${ }^{14} \mathrm{C}$ dates since Scirpus uses atmospheric $\mathrm{CO}_{2}$ and not dissolved $\mathrm{CO}_{2}$, and the pollen- enriched samples did not contain amorphous organic matter of lacustrine origin.

\section{Results}

\subsection{Chronology}


The construction of a chronological model for the Raraku Lake sediments based on AMS ${ }^{14} \mathrm{C}$ dates (Table 1) faced several problems in the uppermost part of the sequence with several age reversal due to: (1) contamination with older organic material during periods of lower lake level and increased erosion of the lake margins, and (2) the contamination with modern Scirpus sp. roots in the samples from the top sedimentary unit. The first process is likely responsible for dates too old in some pollen-enriched samples of subunits 3b and 4b (samples Poz-19934, 24026, 19931, 19940, Table 1). The second process would have caused much younger ages than expected in several samples of Scirpus macrorests from the of top Unit 4 ( Poz-20530, 24023, 24024, 19937, Table 1). These anomalous dates have not been taken into account in the final chronological model, based on 22 radiocarbon dates from the cores RAR7, RAR3, RAR2 and RAR1. Similar difficulties dating different sediment fractions of Kao Lake have been discussed by Butler et al. (2004). The ages of the intermediate samples were calculated by linear interpolation between the radiocarbon dates (Fig. 2). The recovered sedimentary sequence of Raraku Lake spans the last 34000 cal years BP, with a sedimentary hiatus between 5000 and 800 cal. years BP.

\subsection{Sedimentary facies and lithostratigraphy}

The sediments of Raraku Lake are dominated by organic matter (60 to $99 \%$ of the total weight) with variable percentages of terrigenous mineral (volcanic glass, clays, feldspar, iron oxide) particles from the catchment volcanic rocks, and pyrite aggregates precipitated in the lake sediments (Fig. 3). The correlation coefficients show two separate groups: terrigenous inputs and lake organic productivity indicators (Table 2). The geochemical and mineralogical compositions of the terrigenous fraction of the lacustrine sediments reflect the dominant composition of the soils and rocks in the crater around the lake: altered volcanic glass particles (rich in $\mathrm{Si}$ and minor quantities of $\mathrm{Al}$ and $\mathrm{Fe}$ ), kaolinite and ilmenite. Feldspars are also present although most of them are altered to aggregates of kaolinite. Scarce quantities of illite, smectite, quartz, siderite, aragonite, barite, magnetite, heulandite and glauconite have also been identified. Nine main sedimentary facies have been defined integrating lithology, sedimentary textures and structures, color, sediment composition based on smear slide observations, mineralogy and chemical data. Four main lithostratigraphic units have been identified in all the cores and correlated through the basin. A correlation panel reconstructs the architecture of the lake sedimentary infill (Fig. 4). Also litho-, chrono- and biostratigraphical data from 5 littoral cores (Flenley et al., 1991; Dumont et al., 1998, Azizi and Flenley, 2008, Mann et al., 2008) have been included in the stratigraphic correlation.

Unit 1 (>34 - 16.4 cal kyr BP) 
Unit 1 is more than $10 \mathrm{~m}$ thick in the littoral cores (RAR1, 2, 7 and 8). Cores from the center of the lake (RAR 3, 4 and 5) reached this unit, but the total thickness in unknown. Sedimentation rate is the lowest in the sequence $(0.53$ $\mathrm{mm} / \mathrm{yr}$, Fig. 2). Deposits of this unit are mostly composed of laminated, dark grey-reddish organic-rich silts and muds (Facies 1) (Fig. 5A). Lamination is dominantly planar and it is made up of 1 to $2 \mathrm{~mm}$-thick couplets with (1) a lower lighter colored lamina of mud to silt grain size, and (2) an upper darker lamina of silt to very fine sand. The lamination is well recognizable in core radiographies (Fig. 5B) contrasting black and white color of fine (dense) and coarse (light) sediments, respectively. Cross lamination structures caused by current activity and internal erosive surfaces are present. In the lake margin cores, sediments show strong changes in dip, reaching a maximum inclination of $43^{\circ}$.

The laminated grey-reddish silty mud deposits of Unit 1 have TOC values ranging from 20 to $40 \%$, LOI values oscillate between $58 \%$ and $79 \%$, and $\mathrm{TN}$ values up to $1.2 \%$ (Fig. 3). Inc/coh ratio oscillates between 20 and 45 , the lowest values of the whole sequence, reflecting the relatively low organic content of this unit compared to the uppermost ones. $\mathrm{C} / \mathrm{N}$ values, around 20, suggest an important contribution of terrestrial organic matter to the basin (Meyers and Llaier-Verges, 1999). The organic fraction includes particulate organic matter, chrysophyte cysts, phytoliths, pollen and palynomorphs, tricomes and other macrophyte cuticles. Chrysophyte cysts content increase towards the top of the unit in offshore cores. The high organic matter content and the high terrestrial contribution suggest that the lake was dystrophic during deposition of Unit 1. The percentages of the mineral fraction are the largest in all Raraku sequence (21 to $42 \%$ ). This fraction includes major quantities of volcanic glass (spherules and irregular grains), kaolinite aggregates, idiomorphic crystals of ilmenite, and minor quantities of feldspars, quartz and aragonite. Pyrite aggregates are common both isolated or in clusters. The silty-sandy fraction is dominated by volcanic glass altered to kaolinite and mineral silt-sized particles. The high silicate and oxide content of this unit is also reflected in the high values of $\mathrm{Si}, \mathrm{Ca}, \mathrm{Ti}, \mathrm{Fe}$ and $\mathrm{S}$ (Fig. 3).

Fifteen 3-16 mm-thick dark layers, (F1 to F15 in RAR7, Fig. 4) have been identified interbedding the laminated deposits (Facies 2). These layers often show fining-upward textures with: (1) a dark lower interval (black in core radiographies) up to $1.6 \mathrm{~cm}$-thick, with slightly erosive basal surface, structureless or with planar and current lamination, composed of silt to very fine sand rich in mafic particles (such as ilmenite), and (2) an upper, light grey, thin (about $1 \mathrm{~mm}$-thick) interval composed of fine particles and rich in glass. Large peaks in $\mathrm{Si}, \mathrm{Ti}, \mathrm{Fe}$ and $\mathrm{Ca}$ and magnetic susceptibility (Fig. 3) coincide with major layers rich in ilmenite at 32.5 (key bed F2), 27.8 (F4), 25 (F5-6), 23 (F8), 19 (F13-14) cal kyr BP. Two intervals with minor trends of increasing terrigenous elements and magnetic susceptibility can be recognized in this unit (Fig. 3). TS and S contents display a more erratic behavior since they peak in these layers but also in other intervals. The normal graded texture and the sedimentary structures support the interpretation of these layers as terminal lobes deposits in distal and submerged parts of alluvial fan systems. Sedimentation occurred during single events, mainly by quasi-steady hyperpycnal turbidity currents, formed when sediment-laden flood discharges 
entered standing, lower-density lacustrine water bodies (Zavala et al., 2006, Sáez et al., 2007). Moreover, in the northern margin of the lake (RAR2), a $15 \mathrm{~cm}$-thick unique, reddish, structureless, microgravel interval (Facies 3 ) with an erosive bottom surface appears interbedding the mudstone deposits. Clasts in this interval are similar to the Miocene volcanic rocks outcropping in the northern and western margin of the basin. The coarse and massive nature of the deposit suggests a single debris flow event.

Laminated facies 1 are interpreted as lacustrine deposits in a relatively deep lake, with variable alluvial influence and with frequent anoxic bottom conditions, likely caused by dystrophic conditions due to high organic matter accumulation rates. Facies 2 and 3 are interpreted as distal clastic deposits reaching littoral and central areas of a relatively deep lake. High dip of sediment lamination and/or bedding in the littoral fringe of the lake indicates a high gradient of the lake bottom, favored by the high dip of substrate crater.

\section{Unit $2(16.4-8.9$ cal kyr BP)}

The thickness of Unit 2 is maximum ( $7 \mathrm{~m}$ ) in the offshore lake area (cores RAR3, 5, 6) and decreases towards the lake margins where onlaps deposits of Unit 1 (Onlap 1, Fig. 4); Unit 2 is absent in the littoral areas. The sedimentation rate increases with respect to Unit 1 up to $0.94 \mathrm{~mm} /$ year (Fig. 2). Unit 2 is made up of horizontally laminated and massive brownish organic mud (Fig. 5C). Unit 2 deposits are dominated by non-particulate, amorphous organic matter. Chrysophyte cysts and phytoliths are very abundant in the lower part of this unit. Other plant remains such as macrophyte cuticles, pollen, palynomorphs and tricomes can also be found. LOI values, the inc/coh ratio and TOC percentages are the highest of the whole sequence indicating that the terrigenous content of this unit is low $(<10 \%)$. Pyrite aggregates, frequently as clusters, are abundant in the whole unit, increasing towards the top.

Eight coarse grained layers (F16 to F23, in RAR3 Fig. 4), similar in thickness and composition to those from Unit 1 have been identified, mainly in the lower half of the unit (Fig. 5C,D,E). At the base of this unit, two major black layers (F16 and F17), 20 and $10 \mathrm{~cm}$-thick respectively, constitute two key beds useful for the stratigraphic correlation

(Fig. 4). Large peaks of Si, Ti, and Fe correspond with the black layers at 15.5 (key bed F16), 16 (F17), 13 (F21) and 11 cal. kyr BP (F23) (Fig. 3).

From bottom to top, three subunits have been differentiated:

Subunit $2 a(16.4-11.2 \mathrm{kcal}$ yr BP) corresponds to the lower two thirds of Unit 2, and it is made up of laminated facies, with laminae thickness between $0.5 \mathrm{~mm}$ and $5 \mathrm{~mm}$, and the laminae groups in 1-2 $\mathrm{cm}$ thick bundles. The type of lamination and sediment composition change from bottom to top of this subunit. Lamination in the lower part of Subunit 2a is defined by four colors (brown, yellow, red and green) (Facies 4, Fig. 5C,D), suggesting changes in the organic components, although neither smear slide or XRF analysis indicate significant differences in composition. This lamination is not well recognizable in core radiographs (Fig. 5E). These features suggest an organic (algal) origin. TOC 
values display an increasing upwards trend from $15-20 \%$ at the lower half to $60-68 \%$ at the upper half of Subunit $2 \mathrm{a}$, coinciding with the inc/coh ratio profile (Fig. 3). Si, Ti, Fe, Ca and $\mathrm{S}$ have higher values in the lower half of Subunit $2 \mathrm{a}$, paralleling the higher mineral content (kaolinite, ilmenite), up to ca. $12 \mathrm{kyr}$ (Fig. 3). On the other hand, sediments in the upper part of subunit 2a are more organic and the lamination is made up of only two colors (light and dark brown) (Facies 5, Fig. 5F), visible in all core radiographs (Fig. 5G).

Subunit $2 b(11.2-9.4$ kcal yr BP) is made up of massive organic facies (Facies 6). It shows a decreasing TOC and increasing TN trends (Fig. 3) which indicate a higher contribution of phytoplankton to the organic matter accumulated in the lake. Pyrite peaks in this subunit.

Subunit $2 c(9.5-8.9 \mathrm{kcal} \mathrm{yr} \mathrm{BP})$ is a $40 \mathrm{~cm}$ thick interval of muddy-peaty facies (Facies 7), with the highest TN, relatively lower TOC values and transitional features between units 2 and 3 (Fig. 3). C/N values sharply decrease in subunits $2 \mathrm{~b}$ and $2 \mathrm{c}$ (Fig. 3), indicative of a higher lacustrine contribution to the total organic matter deposited in the lake.This trend points to a somewhat relaxation of the dystrophic condition of the lake.

Unit 2 facies association (Facies 4 to 7) is interpreted as deposition in a low gradient, shallow lake dominated by organic sedimentation with a small input of alluvial fine sediments into the lake (subunit 2a) that almost disappeared afterwards (subunits $2 \mathrm{~b}$ and $2 \mathrm{c}$ ). The decreasing terrestrial input could be related to changes in the vegetation cover in the catchment or the run-off intensity. Seasonal or annual changes would have been responsible for the lamination in Subunit $2 \mathrm{a}$ when cyanobacterial or algal activity dominated. The massive nature of the sediments and the $\mathrm{C} / \mathrm{N}$ ratio of the upper subunits $2 \mathrm{~b}$ and $2 \mathrm{c}$ suggest a change in the lake towards shallower conditions and dominance of lake organism as primary organic producers contributing to organic matter deposition after $11 \mathrm{cal} \mathrm{kyr} \mathrm{BP.}$

\section{Unit $3(8.9-4.2$ cal kyr BP)}

Deposits of Unit 3 reach $7 \mathrm{~m}$ maximum thickness in the offshore cores (cores RAR3 to RAR6) and they are absent in littoral cores Fig. 4). Stratigraphic correlation suggests that these sediments onlap Units 2 and 1 at the lake margins (Onlap 2, Fig. 4). The sedimentation rate increases up to $1.48 \mathrm{~mm} /$ year (Fig. 2). This unit is made up of brown-reddish massive or banded peaty sediment, mainly composed by macro and microrests of sedges (Scirpus sp.). TOC values range from 51 to $56 \%$ (99\% of LOI). The $\mathrm{C} / \mathrm{N}$ values reach the maximum of the whole sequence (up to 60, Fig. 3), indicative of dominant terrestrial organic matter and likely enhanced dystrophy of the system. The terrigenous content of this unit is usually lower than 5\%, undetectable by XRD. Low values in $\mathrm{Si}, \mathrm{Ti}, \mathrm{Fe}$ and $\mathrm{S}$, and relatively higher values of Ca characterize Unit 3 (Fig. 3). Carbonate minerals have not been detected by XRD, but they could occur at the base of Unit 3 where TIC content reaches the highest in the sequence $(1 \%)$. Ca content in Unit 3 is not associated to carbonates (TIC values $0-0.4 \%$ ) and it could reflect Ca-bearing organic compounds formed during diagenesis in the 
peaty environment (Zaccone et al., 2007). Two subunits can be recognized in core RAR3 attending to changes in lithology, textural features and sedimentary discontinuities (Fig. 4):

Subunit $3 a$ is composed by highly porous peaty deposits of well-preserved macroremains (steams, roots and seeds) of Scirpus sp. with low mud content ( $1 \%$ ) (Facies 8 , Fig. $5 \mathrm{H})$. Core radiograph images of these deposits have allowed us to differentiate: (1) intervals of massive facies, (2) intervals with vertical stems of Scirpus sp., and (3) intervals with horizontally-layered plant macroremains. Some of these deposits extend laterally all over the basin and they have been used as keybeds in the stratigraphic correlation panel (discontinuous lines in Fig. 4).

Subunit $3 b(6.2-5.8$ cal kyr BP) is a $30 \mathrm{~cm}$-thick interval only recognized in core RAR3. Sediments are a silty peat with fine sand particles of volcanic glass and feldspars (Facies 9). Core radiographs confirm the massive nature of this facies, and the presence of some isolated, small plant remains. The greater terrigenous content is marked by positive peaks in magnetic susceptibility, and a relative decrease in TOC (35-54\%) (Fig. 3). A decrease in the C/N ratio points to a higher content of lacustrine organic matter in the sediments (Fig. 3). This is one of the only two intervals with diatom flora in the whole core. Diatom content is low and preliminary data show that the assemblages are dominated by unidentifiable dissolved fragments of the benthic Pinnularia spp. and by Sellaphora pupula (Kutzing) Mereschkowksy, with the tychopelagic Pseudostaurosira trainorii Morales and Pseudostaurosira neoelliptica (Witkowski) Morales as subdominant taxa. This assemblage suggests a shallow lake environment at the time of deposition.

Peat deposits in Subunit 3a (Facies 8) are interpreted as deposition in a dry to very shallow peatbog dominated by rooted Scirpus vegetation. A similar sedimentary environment occurs in another lake in Easter Island, Rano Aroi, at present. Sedimentological and biological indicators suggest that Facies 9 (Subunit 3b) was deposited during a period of flooding conditions in the peatbog and increased sediment delivery from the watershed. Dominant flooding conditions could create a shallow, low gradient lake with floating Scirpus sp. peat patches as modern Raraku Lake. Water table fluctuations in the peatbog would be responsible for periods of dominant flooded conditions (Facies 9) similar to current conditions alternating with other periods of subaerial exposure of the peatbog (Facies 8).

Unit 4 (850 cal yr BP to the Recent)

Unit 4 spans all over the basin and its thickness ranges from about $40 \mathrm{~cm}$ in the northern lake margin (cores RAR1 and RAR2) to $1.55 \mathrm{~m}$ in offshore core RAR3 (Fig. 4). In the lake margins (RAR1 and 2), sediments of Unit 4 cover deposits of the Unit 1, over a clear erosive surface. In the offshore zones, deposits of Unit 4 (cores RAR3, 4, 5 and, 8) overlap peaty deposits of Unit 3, over an irregular and probably erosive surface. The sedimentation rate is the highest in Raraku sequence, $2.96 \mathrm{~mm} /$ year in core RAR3 (Fig. 2). Sediments are composed by peat and silty peat. Two subunits can be differentiated: 
Subunit $4 a$ is composed by massive peat, very similar to the sediments of Subunit 3a (93-99\% LOI) (Facies 8). XRay Fluorescence, TS, TOC and C/N data are also similar to Unit 3a (Fig. 3). Core radiograph images of these peaty deposits reveal interbedded intervals of (a) vertical and inclined stems of Scirpus sp. up to 7 cm-long (Fig. 5I), and (b) macro plant remains horizontally layered.

Subunit $4 b$ extends all over the lake basin and corresponds to silty peat sediments (72-74 \% LOI) (Facies 9) with a thickness between 5 and $20 \mathrm{~cm}$. The higher terrigenous content of this subunit (silt size particles of volcanic glass and minor quantities of feldspars and magnetite) is responsible for an increase in magnetic susceptibility, Fe and a decrease in TOC, and $\mathrm{C} / \mathrm{N}$ ratios (Fig. 3). Diatoms, phytoliths, and chrysophyte cysts are abundant, while Scirpus sp. macroremains are relatively less abundant than in Subunit 4a. Ostracod, cladoceran and chironomid remains have also been recognized. Diatom assemblages have been studied in littoral and offshore cores. The bottom of this subunit in littoral core RAR08 shows the dominance of Pinnularia joculata (Manguin) Krammer, with other benthic taxa such as Luticola cohnii (Hilse) Mann, Luticola mutica (Kützing) Mann, Mayamaea atomus var. permitis (Hustedt) LangeBertalot, Pinnularia borealis Ehrenberg, Pinnularia dubitabilis var. minor Krammer or Hantzschia amphioxys (Ehrenberg) Smith as accompanying species among others. The top of this subunit is however characterized by the dominance of the tychopelagic Pseudostaurosira trainorii accompanied by Pseudostaurosira neoelliptica. Highly corroded fragments of Pinnularia spp. are also found, although they are scarce. In the offshore cores RAR3 and RAR5, the diatom assemblages throughout the whole Subunit $4 \mathrm{~b}$, are similar to those at the top of core RAR8. In littoral core RAR1 from the northern margin of the lake, tychopelagic diatoms dominate: Pseudostaurosira neoelliptica, is almost the exclusive species at the bottom of the subunit, and becomes co-dominant with Pseudostaurosira trainorii towards the top of subunit $4 \mathrm{~b}$. Dumont et al. (1998) reported a large percentage of aerophilic diatoms in littoral cores but our assemblages, which also include aerophilous forms, are dominated or co-dominated by non-areophilic benthic and tychopelagic taxa. The higher percentages of tychopelagic taxa in our cores must be related to their more offshore and deeper position in the lake compared to the marginal sampling sites by Dumont et al. (1998). On the other hand, the highly corroded and fragmented status of the benthic diatoms found which, in general, did not allow determination to the species level, could be an indication of diatoms transported from the margins to those more pelagic positions.

Subunit $4 \mathrm{~b}$ (Facies 9) represents deposition in a shallow, low gradient lake formed by the flooding of the peatbog developed during deposition of Subunit $4 \mathrm{a}$ (Facies 8). The current lake averages $3 \mathrm{~m}$ depth, although in past decades lake level oscillated among $6 \mathrm{~m}$ and totally dry. At present, the lake has developed a littoral belt of Scirpus sp. and the input of clastic sediments is high, likely favored by the scarcely vegetated catchment and the increased soil erosion induced by cattle farming during the last decades. 


\subsection{Relation with previous core studies}

Unit 1 corresponds to zones I-II of core RRA3 of Flenley et al. (1991) and to zones Z1-Z2 and lower part of zone Z3 of core RRA5 from Azizi and Flenley (2008). The palynological content in both studies indicates forested conditions around Raraku Lake suggestive of cold, but relatively humid climate during zone Z1 (prior to 28.3 cal kyr BP) and more open forest conditions or colder climate up to 17.3 cal kyr BP (Zone 2). At 17.3 cal kyr BP, Azizi and Flenley (2008) data show an abrupt vegetation change to higher values of the trees and shrubs/herbs ratios, and lower values of Tubulifloreae/Palmae and Poaceae/Palmae ratios that correspond to the boundary between our units 1 and 2 . This change is interpreted as a climatic change from cooler and likely drier conditions to warmer and wetter conditions (Azizi and Flenley, 2008) that would continue during deposition of Unit 2. Low resolution palynological data from Flenley et al. (1991) indicate that warm and relatively humid conditions continued during the period of sedimentation of Unit 3.

Deposition of Unit 4 coincides with the period of human occupation of the Easter Island dated by Flenley and King, (1984), Mann et al. (2003), and Hunt and Lipo (2006). Unit 4 correlates with sediments described by other authors (Fig. 4): (a) the 100 cm-thick uppermost interval described by Flenley et al. (1991) in core RRA3, (b) the zones 4 and 5, $45 \mathrm{~cm}$ thick, described by Dumont et al. (1998) in a marginal core, and (c) the $15 \mathrm{~cm}$-thick uppermost interval mineral and charcoal particles rich of core \#1 described by Mann et al. (2003, 2008). The palynological studies of Flenley et al. (1991) describe these upper sediments as very rich in Graminae pollen smaller than 32 microns and relatively poor in Palmae and in Graminae pollen bigger than 32 microns with respect to the underlying sediments. Moreover, Flenley et al. (1991) and Mann et al. (2008) claim that the island was deforested because this period coincides with an abrupt decrease in the trees and shrubs/herbs ratio.

\section{Discussion}

The depositional architecture, including the erosive and onlap surfaces, the changes in lithology and thickness of the identified units and the changes in frequency of flood events reconstructed in the Raraku Lake sedimentary infill contain unique information about relative changes in lake level, clastic sediment delivery and limnological conditions during the last 34000 cal. years BP (Fig. 6). Three major forcings are responsible for the lake level changes and the depositional evolution of Raraku Lake: i) sediment basin infilling processes, ii) climate variability, and iii) human activities.

\subsection{Raraku Lake level changes and flood frequency}


Stratigraphic relationships unraveled by the lateral correlation of 8 cores allow the identification of onlap structures created by rapid changes in the lake level. Minimum variations of water depth during lake level fall episodes can be approximately calculated by the differences in depth between the lower and uppermost points of the onlap surfaces (Fig. 4). Following this methodology, we estimate that a lake level fall episode of more than $13 \mathrm{~m}$ occurred at ca. 17 cal kyr BP prior to the onset of deposition of Unit 2 (Fig. 6). This lake level fall was identified by (1) the onlap of Unit 2 deposits over the Unit 1 towards the margin of the lake (Onlap 1, Fig. 4) and (2) the presence of the two thicker flood events (F16 and F17) at the base of the Unit 2 (Fig. 4), caused by the erosion of Unit 1 deposits from the lake margins. After this minimum, the lake level rose but did not reach the previous lake level. Intermediate lake levels continued until 9.5 cal kyr BP (Fig. 6). This period of intermediate lake levels is characterized by (1) a decreasing trend in clastic input during deposition of the lower part of Subunit 2a, and a progressive diminution of flood events towards the top of the Unit 2, and (2) the deposition of variegated laminated deposits produced by algal mats in the lower part of Unit 2 (Facies 4) that graded into brown laminated facies towards the top of this unit (Facies 5). Between 9.5 and 8.8 cal kyr BP, a second lake level fall episode of about 6 m (Fig. 6) occurred as indicated by (1) the onlap of Unit 3 deposits over sediments of units 2 and 1 towards the margins of the lake (Onlap 2, Fig. 4) and (2) the deposition of massive, muddy peaty facies (Facies 7, Subunit 2c) that represent the transition from laminated facies of Unit 2a to shallow peaty deposits of Unit 3 (Facies 8 and 9). The establishment of shallow sedimentation conditions all over the Raraku Lake basin after 9.5 cal kyr BP (Fig. 6) with the dominance of Scirpus sp. peat likely reflects a combination of climate (decreased water tables as a consequence of lower precipitation - evaporation ratio) and sedimentological (colmatation of the lake basin) factors. A similar trend from open, high gradient lacustrine deposits to shallow, low gradient, lacustrine-marsh peaty conditions is commonly recognized in small lakes in many climatic contexts during lake colmatation process (Sáez and Cabrera, 2002; Ortiz et al., 2004; Lancashire et al., 2007). The low resolution study of Flenley et al. (1991) detected no significant changes in the pollen assemblages during the transition to the Scirpus sp. peat-dominated sediments (Unit 2 to Unit 3 in our cores), suggesting that this change in the Raraku Lake sedimentation could be primarily attributed to a regular and progressive sedimentary basin colmatation process and, secondarily, to climate change.

During deposition of units 3 and 4, flood events are not present in the offshore sediments, probably because of the buffering effect of the Scirpus vegetation belt in the lake margins. Nevertheless, the extensive development of Scirpus sp. in the lake points to the maintenance of the low lake level conditions from 9.5 cal kyr BP to present-day (Fig. 6). This relatively low level during the Holocene would have been favored by a significant decrease in the lake gradient during the last 34000 cal. years BP as a consequence of colmatation processes and infilling of the available accommodation space in the lake basin. However, diatom data from Unit 4 shows the change from an assemblage dominated by benthic (Pinnularia joculata) to tychopelagic (Pseudostaurosira trainorii and Pseudostaurosira 
neoelliptica) taxa from the bottom to the top of Subunit $4 \mathrm{~b}$ suggesting a recent shift to the development of more open water environments due to an increase in water level and/or macrophyte clearance.

\subsection{Easter Island paleoclimatic changes in the South Pacific context}

\subsubsection{Last Glacial Period (34 - 17.3 cal kyr BP)}

High lake level and a relatively high terrigenous input to the lake, including numerous flood events, characterized the Raraku Lake sedimentation between 34 and 17.3 cal kyr BP. Both higher clastic input and higher frequency of flood events indicate increased surface runoff. The observed fluctuations in the Raraku terrigenous input marked by Ti peaks could also indicate stormier (and cooler?) periods (Fig. 6). Similarly, the terrigenous input was the highest during glacial times (33 and 17-16 cal kyr BP) in the marine cores offshore central Chile (Kaiser et al., 2008). Pollen assemblages (Azizi and Flenly, 2008) suggest forested conditions (80-85\% of tree and shrub pollen) around the lake (34-28 cal kyr BP), although the presence of significant amounts of Poaceae would indicate a relatively open forest in a relatively cool climate. The presence of moisture-requiring taxa implies that coolness was the dominant factor. An increase in Poaceae from 28-17 cal kyr BP suggests colder temperatures during the end of oxygen isotope stage 3 and the LGM in the island (Azizi and Flenley, 2008).

Mid- and low-latitude terrestrial pollen records covering the glacial period in the South Pacific region are scarce. For several reasons, some of the available records are not easily interpreted in terms of temperature or humidity fluctuations. Nevertheless, some minor trends of increasing terrigenous content recognized in Unit 1 could correspond to some of the dry-cooling intervals during the glacial period at 29-28 and >24-23.3 cal kyr BP identified in the pollen record (Azizi and Flenley; 2008). Similar cooling periods have been described in mid latitudes of New Zealand (Newnham et al., 2007), Patagonia (Heusser and Heusser, 2003) and offshore Central Chile (Kaiser et al., 2008). Distinctive cold periods in Antarctica occurred later (21-23 and 25-26 kyrs BP, Byrd ice core, EPICA Community Members, 2006). Unfortunately, a detailed lithological correlation between our cores and those collected by Azizi \& Flenley (2008) is not possible, and the two last glacial minor cooling trends (from 27.4 to 26 and from 25.4 to 24.1 cal kyr BP) identified in the pollen record cannot be clearly correlated with those in our geochemical records (for example, from 29 to 28 and from $>24$ to 23.3 cal kyr BP). Different lag-time responses between the vegetation and the lake system, or deficiencies in the chronological models could account for the differences in timing of the two episodes.

From 34 to 17.3 cal. kyr BP, the Raraku Lake sedimentary record supports a scenario of cold temperatures, low evaporation rates, and high water balances in the lake which fit to the progressive increase of maximum summer insolation intensity in the Southern Hemisphere. The Patagonian records and the mid and low-latitude records of the 
South circum Pacific show a stronger-than-today influence of the Antarctic Frontal Zone and an equatorward shift of cold air masses and the westerly winds (Kaplan et al., 2008) (Fig. 6). As a result, whereas South Patagonia areas experienced overall drier conditions during the last glacial period (Markgraf et al. 1992, 2007), cooler and wetter conditions occurred in mid latitudes such as the Chilean Lake District (Lowell et al., 1995; Denton et al., 1999; Moreno et al., 1999), Central Chile (Laguna de Tagua Tagua) (Heusser, 1983; Valero-Garcés et al., 2005), and the Argentinian Andes (Ariztegui et al., 1997) (Fig. 6). This pattern was the result of the northward shift of the southern westerly storm tracks (Markgraf et al., 1992, 2007; Lamy et al., 2004). At lower latitudes, such as Lake Titicaca (Tapia et al. 2003) and several sites of the Andean Altiplano (Latorre et al., 2006), more humid conditions also dominated during glacial times (Fig. 6). In these subtropical latitudes, the intensification of the South American Summer Monsoon during the peak summer insolation of the Southern Hemisphere was responsible for the increased transport of humid air masses from the Atlantic Ocean thorough the Amazon Basin (Placzek et al. 2006).

Pollen data from Azizi and Flenley (2008) suggest that cold was the main factor controlling forest development in Easter Island during glacial times. An open forest occurred between 34 and 28 cal kyr BP, which corresponds to the lower part of Unit 1 characterized by a relatively higher terrigenous input to the lake. Colder temperatures occurred between 28 and 17.3 cal kyr BP limiting forest growth around Raraku Lake. Our sedimentological and geochemical proxies indicate stronger sediment delivery concomitant with a reduced vegetation cover, but also with increased runoff by more abundant and intense precipitation. The 3-D architecture of the infilling suggests a larger and deeper lake during deposition of Unit 1. A stronger influence of the westerlies at the Eastern Island latitudes during the LGM is also supported by Atmospheric and Oceanic General Circulation Model (AOGCM) outputs (Rojas et al., 2008), particularly during winter times. Increased westerlies activity during the LGM could have increased winter rainfall and be conducive to higher run-off and watershed erosion. Cold sea surface temperatures, in parallel to enhanced humidity, higher terrestrial inputs and abundant vegetation in the continent have been documented from the study of marine cores offshore north central Chile $\left(30^{\circ} \mathrm{S}\right)$ (Kaiser et al., 2008). Stronger influence of the Antarctic circumpolar current and an enhancement of the westerlies due to increased temperature gradients and the weakening of the South Pacific Anticyclone (SPA) could have been responsible for the coherent climate patterns in subtropical latitudes of Chile and Eastern Island.

\subsubsection{Last deglaciation (17. 3 to 12.5 cal kyr BP)}

Marine records from offshore central Chile (Kaiser et al., 2008) show that the coldest SSTs occurred around 2321 cal kyr BP, and that deglaciation warming started at around 19 cal kyr BP, synchronously to the Antarctic sea-ice retreat. However, the continent response, both in terms of vegetation and hydrological changes, occurred later, at 17-16 cal kyr BP (Heusser, 1990; Moreno and León, 2003, Valero-Garcés et al., 2005) illustrating a decoupling of the 
atmospheric and oceanographic systems during deglaciation. In Easter Island, the hydrological and vegetational response to deglaciation also occurred at 17.3 cal kyr BP, in accordance with South American and New Zealand continental records (Fig. 6). The end of the glacial period in Raraku Lake corresponds to a large lake level drop at the transition between units 1 and 2 (17.3 cal kyr BP). During this period of low lake levels, detrital deposition was high due the erosion of littoral sediments exposed. The lake level partially recovered and up to 12.5 cal kyr BP the Raraku Lake experienced a decreasing trend in the terrigenous influence in favor of organic matter deposition (Fig. 6). This general trend took place in two consecutive phases (Fig. 6): i) a rapid shift from terrigenous - dominated to organic matter - dominated sedimentation in the lake from 17.3 to 15 cal. kyr BP, and ii) a gradual decrease in the clastic input up to 12.5 cal. kyr BP. These millennial-scale trends occurred during a period of intermediate lake levels, lower than during the LGM (Fig. 6). Termination 1 in Raraku Lake is characterized by a series of events over a period of about 4800 years: (1) an abrupt drop in lake level marking the end of the glacial period, (2) the occurrence of the major flood events F16 and F17 due to a deep erosion of the lake margin sediments (Figs. 3 and 6), (3) the change in the sedimentation from silty muds (Facies 1, Unit 1) to laminated organic sediments (Facies 4, Unit 2, Fig. 4), (4) the development of an onlap 1 surface (Fig. 4) and a significant increase in the sedimentation rate (Fig. 2), and (5) the increase in vegetation cover to a more forested landscape characteristic of a warmer climate after 17.3 cal kyr BP (Azizi \& Flenley, 2008) (Fig. 6).

Equivalent Termination 1 climatic trends as those identified in Raraku Lake, but with slightly different timing have been interpreted by many authors in: (a) mid-latitude terrestrial records from Patagonia and New Zealand, (b), in mid- to low latitude marine records, and (c) in low-latitude terrestrial records of the Altiplano (Fig. 6).

The warming conditions during the Late Quaternary glacial terminations have been related to low precession and high obliquity phases in the orbital forcing (Yuan, 2004; Toggweiler et al., 2006; Pena et al., 2008). The southward shift of storm tracks in the South Pacific close to its present location was more conducive to the establishment of La Niñalike conditions during this period (Yuan, 2004). At the same time, the relaxation of the latitudinal thermal gradient and the expansion of the SPCZ would have increased rainfall in mid to low latitudes where Easter Island is located. The duration of the Termination 1 warming period is related to the time that the westerlies spend to recover from their northerly glacial latitudes (McCulloch et al., 2000). Differences in the beginning and the end of the warming period for the records of Figure 6 can be considered as a consequence of both radiocarbon dating problems and the climate modulation effect by local environmental constrains. In marine cores from offshore central Chile $\left(30^{\circ} \mathrm{S}\right)$, the rise in sea surface temperature started at ca. $19 \mathrm{kyr} \mathrm{BP}$, but the humidity decrease in the adjacent continent occurred around 17-16 cal kyr BP (Kaiser et al., 2008), similarly to our record in Easter Island.

A second warming step of Termination 1 has been described in Antarctic ice cores at 12.5 cal kyr BP (EPICA Community Members, 2006) broadly corresponding in time to the Northern Hemisphere Younger Dryas. Southern mid 
latitude sedimentary records in the Southern Hemisphere such as Taiquemó shows a second warming phase between 14.1 and 13.7 cal kyr BP (Heusser and Heusser, 2006), Huelmo between 14.6 and 12.5 cal kyr BP (Moreno and León, 2003), ODP site 1233 between 12.7 and 12.1 cal kyr BP (Lamy et al, 2007) and all Patagonian records between 15.6 and 15.3 cal kyr BP (McCulloch et al., 2000), and in the low-latitude sedimentary records of Lake Titicaca between 12.5 and 10.1 cal kyr BP (Paduano et al., 2003) and ODP site 1240 between 11.1 and 9.2 cal kyr BP (Pena et al., 2008) (Fig. 6). Other South circum Pacific records from New Zealand (Newnham et al., 2007) and Galápagos (Lea et al., 2006) do not show evidences of this second warming step (Fig. 6). In Raraku Lake, although a second warming phase is not evident from the pollen records, the structure of the last termination defined from the sedimentological and geochemical indicators shows a double step structure (17 - 15 and 15 - 12.5 cal kyr BP) (Fig. 6).

The Raraku Lake record does not show evidences for abrupt short events synchronous to either the Antartic Cold Reversal or the Younger Dryas, but a significant change occurred in lake dynamics at about 12.5 cal kyr BP. The change from four-colored - Facies 4 - to bi-colored muds - Facies 5 - at the upper part of Subunit 2a, and an increase in TN suggesting a shift from terrestrial to lacustrine dominated organic matter during the period $12.5-11.2$ cal kyr BP could reflect the influence of cold spells, although the ascription to the YD or the ACR is not possible with our chronological model. The evidence for the Younger Dryas in the southern Hemisphere is limited: glacier moraines at Cardiel Lake around 11 ka (Ackert et al., 2008) and Lake Titicaca (Baker et al., 2001). Other mid-latitude Andean records such as Puyehue Lake (Bertrand et al., 2008) show a cold event between 13.1 - 12.3 cal kyr BP, preceding the northern hemisphere Younger Dryas by 500 to 1000 years, and likely related to the ACR. Marine records also show a SST plateau between $15-12.5 \mathrm{kyr}$ at about $30 \mathrm{~S}$ (Kaiser et al., 2008) synchronous with the Antarctic Cold Reversal (ACR, 14-12.5 kyr; Jouzel et al., 1995).

\subsubsection{Early to mid Holocene}

The deposition of massive organic deposits (Facies 6 of Subunit 2b) at 11.2 cal kyr BP marks the onset of the Holocene sedimentation in Raraku Lake, characterized by a gradual change from brown organic, laminated sediments (Facies 5, Unit 2) to Scirpus peat (Facies 8, Unit 3). During this transitional period (11.2 to 9.5 cal kyr BP) a decrease in the $\mathrm{C} / \mathrm{N}$ ratio (Subunit $2 \mathrm{~b}$ ) suggests a change to a more algal-dominated environment (Fig. 3). This would be followed by a pronounced lake level decrease (Subunit 2c) associated to the development of a palustrine marginal belt of sedge vegetation, which became a main source of organic matter in the lake as indicated by the increase in the $\mathrm{C} / \mathrm{N}$ ratio. At 9.5 cal kyr BP, the watertable dropped even more, and a peat bog developed all over the basin. Although TOC values diminished compared to those in Unit 2, the high sedimentation rate of Unit 3 (more than 1.5 times higher than the sedimentation rate of Unit 2) indicates an increased organic matter accumulation in the lake during the Holocene with respect to the LGM and Termination 1 periods. This limnological change coincides with the second sedimentary onlap, 
both suggesting a fall of the lake water level leading to dominant very shallow sedimentary conditions up to the mid Holocene (Fig. 6). Arid conditions during the early Holocene also occurred in Central Chile (Laguna Aculeo, $34^{\circ} \mathrm{S}$ ) and they lasted till mid Holocene (from 9.5 till 5.5 cal kyr BP) (Jenny et al., 2002). Offshore central Chile maximum SSTs (ca $19^{\circ} \mathrm{C}$ ) occurred during the early to mid Holocene (Kaiser et al., 2008). A strong link between southern hemisphere summer insolation (with minima during the early Holocene and increasing values up to the present) and moisture changes is considered as the main driver for variations in water availability in central Chile during the Holocene (Lamy et al., 2001; Jenny et al., 2002; Latorre et al., 2006). In Easter Island, after the lake level dropped during the Early Holocene (9.5 cal kyr BP), very shallow peatbog conditions dominated until mid Holocene. However, the deposition of siliciclastic and diatom-rich sediments (Facies 9, Subunit 3b) in some areas (northwestern core RAR3) of the lake from 6.2 to 5.8 cal kyr BP would indicate short-term (century - scale) fluctuations in watertable levels during the mid Holocene leading to flooded conditions and the development of a mosaic of shallow lakes and peat bogs. During these short periods, increased nutrient availability as a consequence of higher runoff and clastic inputs favored planktonic and algal productivity.

\subsubsection{Mid to Late Holocene aridity}

The correlation of the cores along the Raraku Lake basin demonstrates that the sedimentary gap described by previous studies in littoral cores occurs all over the basin. This sedimentary hiatus dated between $\sim 5$ and $\sim 0.8$ cal kyr $\mathrm{BP}$ is bounded by an erosive unconformity between peaty deposits (Facies 8) of Unit 3 and Unit 4 . No paleosoil horizons or charcoal remains have been detected in the erosive contact of Unit 3 and Unit 4 as would be expected if large vegetation fires or long periods of subaerial exposure had occurred. However, it is not unlikely that erosion during a dry period had eroded away part of the sediments and with them, the evidences for subaerial exposure. The erosive nature of the unconformity is supported by the asynchrony of the youngest offshore sediments of Unit 3 (from 4.2 to 5.8 cal yr BP) below the discontinuity and by the age of the oldest deposits of Unit 4 above the discontinuity (from 850 to 500 cal yr BP). The timing of the unconformity suggests a relation with the mid Holocene aridity crises documented elsewhere in the circum Pacific area. Dry mid Holocene periods in low Andean latitudes are broadly coetaneous to that detected in Easter Island (Fig. 6). These dry conditions in low latitudes have been explained as a result of the austral summer insolation minimum during early to mid Holocene and the subsequent weakening of the summer monsoon (Tapia et al., 2003; Latorre et al., 2006; Placzek et al., 2006). Holocene dry periods in Patagonian mid latitudes (Moreno and León, 2003 or Maldonado and Villagrán, 2006), have been explained by the southern shift of storm tracks forced by "El Niño-like" dominant conditions in south Pacific during some periods (Moy et al., 2002; Yamamoto, 2004). Similar atmospheric mechanisms would have produced Holocene dry conditions in Easter Island. 
5.3 The last 800 years: the interplay between human activities and climate oscillations

A detailed paleoclimatic and paleoenvironmental reconstruction for the last 800 years is difficult to carry out due to the problems of obtaining reliable radiocarbon dates from these sediments. Our data confirm the hypothesis of the onset of a more humid period in the island at about 800 years ago, ending a long arid period - although with some humid fluctuations - during the mid to late Holocene. Evidences for this change occur in the top interval described by Flenley et al. (1991) with large changes in vegetation assemblages. There are some evidences elsewhere in Oceania and Patagonia of precipitation increases ca. AD 1300 at the beginning of the Little Ice Age cronozone (Stine, 1994; Villalba et al., 1998; Nunn, 2000; Moy et al., 2002; Nunn et al., 2007; Haberzettl et al., 2007), after a generally dry period between 900 and 1100 AD roughly coincident with the Medieval Climate Anomaly cronozone. The timing corresponds with the Polynesian colonization of the island as documented by recent archaeological (Hunt and Lipo, 2006) and charcoal data (Mann et al., 2008). More humid conditions could have been caused by stronger westerlies that could also have favored the migrations of Polynesian people in the South Pacific. To confirm this theory, high resolution pollen studies are in progress in the post-erosive surface interval to identify the possible man-induced deforestation described in Flenley et al (1991), Mann et al. (2008) and Prebble and Dowe (2008). The renew deposition of Scirpus-dominated sediments (Facies 8) after 800 cal yr BP (onset of Subunit 4a) suggests that conditions in Raraku Lake when Polynesian reached the Island where similar to those during the early Holocene (Unit 3) and the impact in the peatbog was small for several centuries. However, the top sediments (Facies 9, Subunit 4b) clearly indicate a limnological change in the lake, with increased water level, as shown by the change from benthic- to tychopelagic-dominated diatom assemblages, and also enhanced sediment delivery during recent times. Evidences for this change have been identified in other previously studied cores: i) zones 4 and 5 described by Dumont et al. (1998) showed increased inputs of terrigenous particles and changes in diatom assemblages, and ii) the $15 \mathrm{~cm}$-thick uppermost interval rich in mineral and charcoal particles of core \#1 described by Mann et al. (2003, 2008). Human activities in the lake and in the watershed included the deforestation after the 13th century, and the lake siltation and eutrophization related to the Moai quarry surrounding Raraku crater. A period of increased soil erosion after AD 1280 clearly identified in the Poike area (Mieth and Bork, 2005) continued until the $20^{\text {th }}$ century. During the last century, intensive cattle farming (Porteus, 1978) would have contributed to an increase in both sediment delivery to the lake and eutrophization.

The change in the pollen assemblages recorded in the upper part of Raraku Lake sequence (from Unit 3 to Unit 4) is mainly a reflection of the palm forest reduction in the island (Flenley et al., 1991). Nevertheless, the timing for the onset of this deforestation remains uncertain because of the discontinuity in the sedimentary record and the lack of sediments from 4.2 to 0.8 cal kyr BP. So far, none of the available sequences have a robust chronology to ascribe the 
top interval with increased sediment delivery to the lake either to the moai culture or to the large changes that occurred in the island after the European colonization.

\section{Conclusions}

A high-resolution sedimentological and geochemical study of the Raraku Lake sediments documents large hydrological changes in Eastern Island during the last 34000 cal. years BP. The glacial period was characterized by cold and relatively humid conditions between 34 to 28 cal kyr BP. High lake levels and clastic dominated sedimentation occurred in Raraku Lake and pollen data (Azizi and Flenley, 2008) indicate the presence of an open forest at that time. Colder conditions between 28 and 17.3 cal kyr BP contributed to a relatively increase of clastic input to the lake and a reduction of the tree coverage in the island. During glacial times and the LGM, clastic sedimentation was enhanced by the steep lake margins and the occurrence of periods with lower vegetation cover and increased runoff. Lake levels were relatively high favored by low evaporation rates.

The end of the glacial period occurred at 17.3 cal kyr BP and it was characterized by an abrupt drop in lake level (up to $13 \mathrm{~m}$ ) conducive to the development of major turbidite-like floods due to the erosion of littoral sediments. Lake productivity and terrigenous input show a double phase structure for Termination 1 (17.3 to 12.5 cal kyr BP). A rapid lake level recovery inaugurated this period of intermediate lake levels, and dominance of algal lamination. The timing and duration of the warming trend during the Termination 1 in Easter Island $\left(27^{\circ} \mathrm{S}\right)$ broadly agrees with the mid- and low latitude circum South Pacific records. Precipitation changes were mainly driven by latitudinal shifts of the southern westerly storm tracks as supported by modeling results. During glacial times, relatively wetter conditions could have been a result of colder temperature and decreased evaporation but also a result of intensified westerlies over the island due to a northward shift of the storm belts. During Termination 1, the expansion of the SPCZ, and the southward shift of the storm tracks in the South Pacific close to its present location were conducive to more dominant "La Niña-like" conditions in the southern Pacific. This situation could have increased rainfall in Easter Island but also temperature and evaporation.

Although some limnological changes occurred around 12.5 cal kyr BP, their relationship with cold spells in the southern hemisphere is not clear. At 11.2 cal kyr BP, deposition of massive, organic facies inaugurated the trend towards lower lake levels during the Pleistocene/Holocene transition and the early Holocene. After a lake level drop, during the early Holocene (ca. 9.5 cal yr BP), peatbog and shallow lake conditions dominated till mid Holocene, partially caused by the sedimentary colmatation of the lacustrine basin. Intense drought periods occurred during the mid and late Holocene and led to a persistent low water table period, subaerial exposure and erosion of some of the sediments, generating a sedimentary gap in the Raraku sequence, from 4.2 to 0.8 cal kyr BP. 
The palm deforestation of the Eastern Island, attributed to the human colonization at about 850 cal yr BP, could have started earlier, since the decline in Palmae pollen highlighted by Flenley et al. (1992) could have started during the 4.2 to 0.8 cal kyr BP period when there is no sedimentary record. The colonization of the island coincides with a new humid episode that started 800 yrs ago. From the second half of the 20th century to the present, an increase in water table flooded the peatbog and a shallow lake similar to the present day environment developed. The lake has suffered an eutrophization process probably due to the intensive cattle exploitation in the island.

\section{Acknowledgments}

The Spanish Ministry of Science and Education funded the research at Raraku Lake through the projects LAVOLTER (CGL2004-00683/BTE) and GEOBILA (CGL2007-60932/BTE) and CONSOLIDER GRACCIE (CSD2007-00067). . The Limnological Research Center and the Large Lake Observatory (University of Minnesota, USA) are acknowledged for technical assistance with the XRF-Core Scanner analyses. We acknowledge fellowship to

A. Moreno from the European Comission's Sixth Framework Program (Marie Curie Fellowship 021673 IBERABRUPT). We are grateful to CONAF (Chile) and Riroroko family for the facilities provided in Easter Island. We are also very thankful to Eduardo Morales, for his assistance in the diatom identification of the small Pseudostaurosira species found in the samples and to Almudena Lorenzo for the assistance in the organic analysis. 


\section{References}

Ackert, R.P., Becker, R.A., Singer, B.S., Kurz, M.D. Caffee, M.W., Mickelson, D.M., 2008. Patagonian glacier response during the late Glacial-Holocene trasition. Science 321, 392-395.

Ariztegui, D., Bianchi, M.M., Masaferro, J., Lafargue, E., Niessen, F. 1997. Interhemispheric synchrony of late-glacial climatic instability as recorded in proglacial Lake Mascardi, Argentina. Journal of Quaternary Science 12, 333-338.

Azizi, G., Flenley, J.R., 2008. The last glacial maximum climatic conditions on Easter Island. Quaternary Internacional 184, 166-176.

Berger A., Loutre, M.F., 1991. Insolation values for the climate of the last 10 million years. Quaternary Science Reviews 10, 297-317.

Beaufort L., de Garidel-Thoron, T., Mix, A., Pisias, N.G., 2001. ENSO-Like Forcing on Oceanic Primary Production During the Late Pleistocene, Science 293, 2440-2444.

Bertrand, S., Charlet, F., Charlier, B., Renson, V., Fagel, N., 2008. Climate variability of southern Chile since the Last Glacial Maximum: a continuous sedimentological record from Lago Puyehue (40º S). Journal of Paleolimnology 39 , 179-195. doi 10.1007/s10933-007-9117-y

Butler, K., Prior, C.A., Flenley, J.R., 2004. Anomalous radiocarbon dates from Easter Island. Radiocarbon 46, 395,405

Burjachs, F., López-Sáez, J.A., Iriarte, M.J., 2003. Metodología arqueopalinológica. In: R. Buxó and R. Piqué (Eds.), La recogida de muestras en arqueobotánica: objetivos y propuestas metodológicas, Museu d'Arqueologia de Catalunya. Barcelona, pp. 11-18 (in Spanish).

Chung, F.H., 1974. Quantitative interpretation of X-Ray diffraction patterns of mixtures. J. Appl. Cryst. 7, 519-531.

Croudace, I.W., Rindby, A. and Rothwell, R.G., 2006. ITRAX: description and evaluation of a new multi-function Xray core scanner. In: R.G. Rothwell (Ed.), New techniques in sediment core analysis. The Geological Society of London, London, pp. 51-63.

Cruz, F.W., Burns, S.J., Karmann, I., Sharp, W.D., Vuille, M., Cardoso, A.O., Ferrari, J.A., Silva Dias, P.L., Viana, O., 2005. Insolation-driven changes in atmospheric circulation over the past 116,000 years in subtropical Brazil. Nature 434, 63-66.

Danzeglocke, U., Jöris, O., Weninger, B., 2008. CalPal-2007 online. http://www.calpal-online.de/, accessed 2008.05.03

Denton, G.H., Heusser, C.J., Lowell, T.V., Moreno, P.I., Andersen, B.G., Heusser, L.E., Schluchter, C., Marchant, D.R., 1999. Interhemispheric linkage of paleoclimate during the last glaciation. Geogra.ska Annaler Series A - Physical Geography 81A, 107-153. 
Dumont, H.J., Cocquyt, Fontugne, M., Arnold, M., Reyss, J.-L., Bloemendal, J., Oldfield, F., Steenbergen, C.L.M., Korthals, H.J., Zeeb, B.A., 1998. The end of moai quarrying and its effect on Rano Raraku, Easter Island. Journal of Paleolimnology 20, 409-422.

EPICA Community Members, 2006. One-to-one coupling of glacial climate variability in Greenland and Antarctica. Nature 444, 195-198.

Flenley, J. R., King, S.M., 1984. Late quaternary pollen records from Easter Island. Nature 307, 47-50.

Flenley, J.R., King, S.M., Jackson, J., Chew, C., Teller, J.T., Prentince, M.E., 1991. The Late Quaternary vegetational and climatic history of Easter Island. Journal of Quaternary Science 6, 85-115.

Garreaud, R., Aceituno, P., 2001. Interannual rainfall variability over the South American Altiplano. J. Clim. 14, 27792789.

Geller, G., 1992. The temperature stratification and related characteristics of Chilean lakes in midsummer. Aquatic Sciences 54, 37-57.

Giralt, S., Moreno, A., Bao, R., Sáez, A., Prego, R., Valero-Garcés, B., Pueyo, J.J., González-Samperiz, P., Taberner, C., 2008. A statistical approach to disentangle environmental forcings in a lacustrine record: the Lago Chungará case (Chilean Altiplano). Journal of Paleolimnology 40, 195-215.

Goeury, Cl., de Beaulieu, J.L. 1979. Á propos de la concentration du pollen à l'aide de la liqueur de Thoulet dans les sèdiments minèraux. Pollen et Spores, 21: 239-251.

González-Ferran, O., Mazzuoli, R., Lahsen, A., 2004. Geología del Complejo Volcánico Isla de Pascua Rapa Nui. Centro de Estudios Volcánologicos (Ed.). Santiago-Chile. 1:30.000 Geol. map. (in Spanish).

Haberzettl, T., Corbella, H., Fey, M. Janssen, S., Lücke, A., Mayr, C., Ohlendorf, C., Schäbitz, F., Schleser, G.H., Wille, M., Wulf, S., Zolitschka, B., 2007. Lateglacial and Holocene humid-dry cycles in southern Patagonia: chronology, sedimentology and geochemistry of a lacustrine record from Laguna Potrok Aike, Argentina. The Holocene $17,297-310$.

Herrera, C., Custodio, E., 2008. Conceptual Hydrogeological model of volcanic Easter Island (Chile) after chemical and isotopic surveys. Hydrogeology Journal. doi: 10.1007/s10040-008-0316-z

Heusser, C.J,. 1983. Quaternary pollen record from Laguna de Tagua Tagua, Chile. Science 219, 1429-1432.

Heusser, C.J,. 1990. Ice age vegetation and climate of subtropical Chile. Palaeogeography, Palaeoclimatology, Palaeoecology 80, 107-127.

Heusser, C.J., Heusser, L.E., 2006. Submillennial palynology and palaeoecology of the last glaciation at Taiquemó (50000 cal yr, MIS 2-4) in southern Chile. Quaternary Science Reviews 25, 446-454. 
Hunt, T. L., Lipo, C.P., 2006. Late Colonization of Eastern Island. Nature 311, 1603-1606.

Jenny, B., Valero-Garcés, B.L., Villa-Martinez, R., Urrutia, R., Geyh, M., Veit, H., 2002. Early to mid-Holocene aridity in central Chile and the southern westerlies: the Laguna Aculeo record (34 $\left.{ }^{\circ} \mathrm{S}\right)$. Quaternary Research 58, 160-170.

Jouzel, J., Vaikmae, R., Petit, J.R., Martin, M., Duclos, Y., Stievenard, M., Lorius, C., Toots, M., Melieres, M.A., Burckle, L.H., Barkov, N.I., Kotlyakov, V.M., 1995. The 2- step shape and timing of the last deglaciation in Antarctica. Climate Dynamics 11, 151-161.

Kaiser, J., Lamy, F., Hebbeln, D., 2005. A 70-kyr sea surface temperature record off southern Chile (ODP Site 1233). Paleoceanography 20, PA4009. doi:10.1029/2005PA001146.

Kaiser, J., Schefuß, E., Lamy, F., Mohtadi, M., Hebbeln, D., 2008. Glacial to Holocene changes in sea surface temperature and coastal vegetation in north central Chile: high versus low latitude forcing. Quaternary Science Reviews $27,2064-2075$.

Kaplan, M.R., Fogwill, C.J., Sugden, D.E., Hulton, N.R.J., Kubik P.W., Freeman, S.P.H.T., 2008. Southern Patagonian glacial chronology for the Last Glacial period and implications for Southern Ocean climate. Quaternary Science Reviews 27, 284-294.

Koutavas, A., Lynch-Stieglitz, J., Marchitto Jr. T.M., Sachs, J.P., 2002. El Niño-Like Pattern in Ice Age Tropical Pacific Sea Surface Temperature. Science 297, 226-230.

Lancashire A.K., Flenley, J.R., Harper, M., 2002. Late Glacial beech forest: an 18,000-5000 BP pollen record from Auckland, New Zealand. Global and Planetary Change 33, 315-327.

Lamy, F., Hebbeln, D., Wefer, G. 1998. Late Quaternary precessional cycles of terrigenous sediment input off the Norte Chico, Chile (27.5S) and palaeoclimatic implications. Palaeogeography, Palaeoclimatology, Palaeoecology 141, 233251.

Lamy, F., Hebbeln, D., Röhl, U., Wefer, G. 2001. Holocene rainfall variability in southern Chile: a marine record of latitudinal shifts of the Southern Westerlies. Earth and Planetary Science Letters 185, 369-382.

Lamy, F., Kaiser, J., Ninnemann, U., Hebbeln, D., Arz, H.W., Stoner, J., 2004. Antarctic timing of surface water changes off Chile and Patagonian ice sheet response. Science 304, 1959-1962.

Lamy, F., Kaiser, J., Arz, H.W., Hebbeln, D., Ninnemann, U., Timm, O., Timmermann, A., Toggweiler, J.R., 2007. Modulation of the bipolar seesaw in the Southeast Pacific during Termination 1. Earth and Planetary Science Letters $259,400-423$.

Latorre, C.; Betancourt, J.L.; Arroyo, M.Y.K., 2006. Late Quaternary vegetation and climate history of a perennial river canyon in the Río Salado basin $\left(22^{\circ} \mathrm{S}\right)$ of Northern Chile. Quaternary Research $65,450-466$. 
Lea, D.W., Pak, D.K., Belanger, C.L., Spero, H.J., Hall, M.A., Shackleton, N.J., 2006. Paleoclimate history of Galápagos surface waters over the last 135000 yr. Quaternary Science Reviews 25, 1152-1167.

Lowell, T.V., Heusser, C.J., Andersen, B.G., Moreno, P.I., Hauser, A., Heusser, L.E., Schlüter, C., Marchant, D.R., Denton, G.H., 1995. Interhemispheric correlation of Late Pleistocene glacial events. Science 269, 1541-1549.

Maldonado, A., Villagrán, C., 2006. Climate variability over the last 9900 cal yr BP from a swamp forest pollen record along the semiarid coast of Chile. Quaternary Research 66, 246-258

Mann, D., Chase, J., Edwards, J., Beck, W., Reanier, R., Mass, M., 2003. Prehistoric destruction of the primeval soils and vegetation of Rapa Nui (Isla de Pascua, Easter Island). In: Loret, J., Tanacredi, J.T. (Eds.), Easter Island: Scientific Exploration into the World's Environmental Problems in Microcosm. Kluwer Academic/Plenum, New York, pp. 133153.

Mann, D., Edwards, J., Chase, J., Beck, W., Reanier, R., Mass, M, Finney, B., Loret, J., 2008. Drought, vegetation change, and human history on Rapa Nui (Isla de Pascua, Easter Island). Quaternary Research 69, 201-206.

Markgraf, V., Dodson, J.R., Kershaw, P.A., McGlone, M., Nicholls, N., 1992. Evolution of late Pleistocene and Holocene climates in the circum South Pacific land areas. Climate Dynamics 6, 193-211

Markgraf, V., Whitlock , C., Haberle, S., 2007.Vegetation and fire history during the last 18,000 cal yr B.P. in Southern

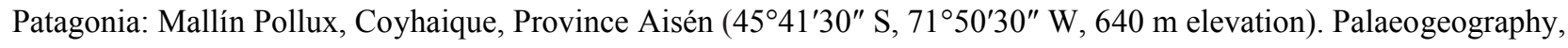
Palaeoclimatology, Palaeoecology 254, 492-507

McCulloch, R.D., Bentley, M.J., Purves, R.S., Hulton, N.R.J., Sugden, D.E., Clapperton, C.M., 2000. Climatic inferences from glacial and palaeoecological evidence at the last glacial termination, southern South America. Journal of Quaternary Sciences 15, 409-417.

McGlone, M.S., 2002. The Late Quaternary peat, vegetation and climate history of the Southern Oceanic Islands of New Zealand. Quaternary Science Reviews 21, 683-707

Meyers, P.A., Lallier-Vergès, E., 1999. Lacustrine sedimentary organic matter records of Late Quaternary paleoclimates. Journal of Paleolimnology 21, 345-372.

Meith, A., Bork, H.-R., 2005. History, origin and extent of soil erosion on Easter Island (Rapa Nui). Catena 63, 244260.

Moreno, A., Giralt, S., Valero-Garcés, B. L., Sáez, A., Bao, R., Prego, R., Pueyo, J.J., González-Sampériz, P., Taberner, C. 2007. A 14-kyr record from the tropical Andes: the Lago Chungará sequence ( $18^{\circ} \mathrm{S}$, northern Chilean Altiplano). Quaternary International 161, 4-21. 
Moreno, P.I., Jacobson, G.L., Andersen, B.G., Lowell, T.V., Denton, G.H., 1999. Vegetation and climate changes during the last glacial maximum and the last Termination in the Chilean Lake District: a case study from Canal de la Puntilla (41 $\left.{ }^{\circ} \mathrm{S}\right)$. Geografiska Annaler Series A-Physical Geography 81A, 285-311.

Moreno, P.I., León AL., 2003. Abrupt vegetation changes during the last glacial to Holocene transition in mid-latitude South America. Journal of Quaternary Science 18, 787-800.

Moy, C.M., Seltzer, G.O., Rodbell, D.T., Anderson, D.M., 2002. Variability of El Niño/Southern Oscillation activity at millennial timescales during the Holocene epoch. Nature 420, 162-164.

Mucciarone D.A., Dunbar, R.B., 2003. Stable Isotope Record of El Niño-Southern Oscillation Events from Eastern Island. In: Loret, J., Tanacredi, J.T. (Eds.), Easter Island: Scientific Exploration into the World's Environmental Problems in Microcosm. Kluwer Academic/Plenum, New York, pp. 113-132.

Negri, A.J., Adler, R.F., Shepherd, J.M., Huffman, G., Manyin, M., Neklin, E.J., 2004. A 16-year climatology of global rainfall from SSM/I highlighting morning versus evening differences. 13th Conference on Satellite Meteorology and Oceanography, Norfolk, VA, American Meteorological Society, P6.16.

Newnham, R.M., Vandergoes, M.J., Hendy, C.H., Lowe, D.J., Preusser, F., 2007. A terrestrial palynological record for the last two glacial cycles from southwestern New Zealand. Quaternary Science Reviews 26, 517-535

Nunn, P.D., 2000. Environmental Catastrophe in the Pacific Islands about A.D. 1300. Geoarchaeology 15, $715-740$.

Nunn P.D., Hunter-Anderson, R., Carson, M.T., Thomas, F., Ulm, S., Rowland, M.J., 2007. Times of Plenty, Times of Less: Last-Millennium Societal Disruption in the Pacific Basin. Human Ecology 35, 385-401

Ortiz, J.E. Torres, T., Delgado, A., Julià, R., Lucini, M., Llamas, F.J., Reyes, E., Soler, V., Valle. M., 2004. The palaeoenvironmental and palaeohydrological evolution of Padul Peat Bog (Granada, Spain) over one million years, from elemental, isotopic and molecular organic geochemical proxies. Organic Geochemistry 35, 1243-1260.

Paduano, G.M., Bush, M.B., Baker, P.A. Fritz, S.C., Seltzer, G.O., 2003. A vegetation and fire history of Lake Titicaca since the Last Glacial Maximum. Palaeogeography, Palaeoclimatology, Palaeoecology 194, 259-279

Pena, L.D., Cacho, I., Ferretti, P., Hall, M.A. 2008. ENSO-like Variability during Glacial Terminations and Interlatitudinal Tele-connections. Paleoceanography 23, PA3210.

Placzek, C., Quade, J., Patchett, P., 2006. Geochronology and stratigraphy of late Pleistocene lake cycles on the southern Bolivian Altiplano: Implications for causes of tropical climate change. Geol Soc Am Bull 118, 515-532

Porteous, J.D., 1978. Easter Island: The Scottish Connection. Geographical Review 68, 145-156. 
Prebble, M., Dowe, J.L, 2008. The Late Quaternary decline and the extinction of palms on oceanic Pacific islands. Quaternary Science Reviews 27, 2546-2567.

R Development Core Team, 2008. R: A Language and Environment for Statistical Computing. R Foundation for Statistical Computing, Vienna, Austria ISBN 3-900051-07-0. URL http://www.R-project.org.

Reimer, P.J., Baillie, M.G.L, Bard, E., Bayliss, A., Beck, J.W., Bertrand, C.J.H, Blackwell, P.G., Buck, C.E., Burr, G.S., Cutler, K.B., Damon, P.E., Edwards, R.L., Fairbanks, R.G., Friedrich, M., Guilderson, T.P., Hogg, A.G., Hughen, K.A., Kromer, B., McCormac, G., Manning, S., Ramsey, C.B., Reimer, R.W., Remmele, S., Southon, J.R., Stuiver, M., Talamo, S., Taylor, F.W., van der Plicht, J., Weyhenmeyer, C.E., 2004. IntCal04 terrestrial radiocarbon age calibration, 0-26 cal kyr BP. Radiocarbon 46, 1029-1058.

Renberg, I., 1990. A procedure for preparing large sets of diatom slides from sediment cores. Journal of Paleolimnology 4, 8790.

Rind, D., Chandler, M., Lerner, J., Martinson, D.G., Yuan, X., 2001. The climate response to basin-specific changes in latitudinal temperature gradients and the implications for sea ice variability. Journal of Geophysical Research 106, 20161-20173.

Rojas, M., Moreno, P., Kageyama, M., Crucifix, M., Hewitt, C., Abe-Ouchi, A., Ohgaito, R., Brady, E.C., Hope, P., 2008. The Southern Westerlies during the last glacial maximum in PMIP2 simulations. Climate Dynamics, doi 10.1007/s00382-008-0421-7

Sáez, A.; Anadón, P.; Herrero, M.J.; Moscariello, A., 2007. Variable style of transition between Palaeogene fluvial fan and lacustrine systems, Southern Pyrenean Foreland, NE Spain. Sedimentology 54, 367-390.

Sáez, A., Cabrera, L., 2002. Sedimentological and palaeohydrological responses to tectonics and climate in a small, closed lacustrine system: Oligocene As Pontes Basin (Spain). Sedimentology 49, 1073-1094

Sáez, A., Valero-Garcés, B.L., Moreno, A., Bao, R., Pueyo, J.J., González-Sampériz, P., Giralt, S., Taberner, C., Herrera, C., Gibert, R.O., 2007, Lacustrine sedimentation in active volcanic settings: the Late Quaternary depositional evolution of Lake Chungará (northern Chile). Sedimentology 54, 1191-1222.

Stine, S., 1994. Extreme and persistent drought in California and Patagonia during mediaeval time. Nature 369, 546549 .

Stott, L., Poulse, C., Lund, S., Thunell, R., 2002. Super ENSO and Global Climate Oscillations at Millennial Time Scales. Science 297, 222-226.

Stott, L., Timmermann, A., Thunell, R., 2007. Southern hemisphere and deep-sea warming led deglacial atmospheric $\mathrm{CO} 2$ rise and tropical warming. Science $318,435-438$ 
Stuut, J.B., Lamy, F., 2004. Climate variability at the southern boundaries of the Namib (southwestern Africa) and Atacama (northern Chile) coastal deserts during the last 120,000 years. Quaternary Research 62, 301-309.

Tapia, P.M., Fritz, S.C., Baker, P.A., Seltzer, G.O., Dunbar, R.B., 2003. A Late Quaternary diatom record of tropical climatic history from Lake Titicaca (Peru and Bolivia). Palaeogeography, Palaeoclimatology, Palaeoecology 194, 139164

Toggweiler, J.R.; Russell, J.L., Carson, S.R., 2006. Midlatitude westerlies, atmospheric CO2, and climate change during the ice ages. Paleoceanography 21, PA2005, doi: 2010.1029/2005PA001254.

Tudhope, A.W., Chilcott, C.P., McCulloch, M.T., Cook, E.R., Chappell, J., Ellam, R.M., Lea, D. W., Lough, J.M., Schmmieeld, G.B., 2001. Variability in the El Niño-Southern Oscillation thorough a Glacial-Interglacial Cycle. Science 291, 1511-1517.

Valero-Garcés, B.L., Jenny, B., Rondanelli, M., Delgado-Huertas, A., Burns, S. J., Veit, H., Moreno, A. 2005.

Palaeohydrology of Laguna de Tagua Tagua $\left(34-30^{\circ} \mathrm{S}\right)$ and moisture fluctuations in Central Chile for the last $46000 \mathrm{yr}$. Journal Quaternary Science 20, 625-641.

Vandergoes, M.J., Newnham, R.M. Preusser, F., Hendy, C.H., Lowell, T.V., Fitzsimons, S.J., Hogg, A.G., Kasper H.U., Schluchter, C., 2005. Regional insolation forcing of late Quaternary climate change in the Southern Hemisphere. Nature 436, 242-245.

Villalba, R., Cook, E.R., Jacoby, G.C., D'Arrigo, R.D., Veblen, T.T., Jones P.D. 1998. Tree-ring based reconstructions of northern Patagonia precipitation since AD 1600. Holocene 8, 659-674.

Whitlock C., Moreno P.I., Bartlein, P., 2007. Climatic controls of Holocene fire patterns in southern South America. Quaternary Research 68, 28-36

Yamamoto, M., 2004. Have the Tropical Pacific Ocean-Atmosphere Interactions Behaved as a Driver of Centennial- to Orbital-Scale Climate Changes ?. In: M. Shiyomi, H. Kawahata, H. Koizumi, A.Tsuda, Y. Awaya, (Eds.), Global Environmental Change in the Ocean and Land, TERRAPUB, Tokyo, pp. 265-278.

Yuan, X., 2004. ENSO-related impacts on Antarctic sea ice: a synthesis of phenomenon and mechanisms. Antarct. Sci., $16,415-425$.

Zaccone, C., Cocozza, C., Cheburkin, A.K., Shotyk, W. Miano, T.M., 2007. Enrichment and depletion of major and trace elements, and radionuclides in ombrotrophic raw peat and corresponding humic acids. Geoderma 141, $235-246$.

Zavala, C., Ponce, J.J., Arcuri, M., Drittanti, D., Freije, H., Asencio, M., 2006. Ancient lacustrine hyperpycnites: A depositional model from a case study in the Rayoso Formation (Cretaceous) of west-central Argentina. Journal Sedimentary Research 76, 41-59. 


\section{Figure captions}

Figure 1. Location of Easter Island and the other paleoclimatic records discussed in the text and Fig. 6 (numbers refer to Fig. 6 records) on a South Pacific rainfall rate map (mm/month) simplified from Negri et al. (2004). Main atmospheric systems are indicated.

Figure 2. Sedimentation rate changes for the recovered Raraku Lake succession. Error bars for each point are shown. Date points are from samples of cores RAR1, 2, 3 and 7 correlated to the composite log.

Figure 3. Main paleoenvironmental proxies analyzed in the composite sequence of Raraku Lake versus depth. Kaolinite, illmenite and pyrite (in relative percentages) are the main minerals (besides the volcanic glass) of the terrigenous fraction; Si, Fe, S and Ti (in counts per second, cps) are the main chemical components of those minerals. Relative high values in MS, Si, Fe, S and Ti (significantly in Unit 1) indicate high clastic inputs to the lake during periods of reduced vegetation cover mainly due to cold conditions. Warmer and/or humid periods characterized by increased organic matter deposition are represented by TOC and inc/coh ratio high values (Units 2 to 4). Positive abrupt peaks in MS and the terrigenous components indicate the occurrence of turbidite-like flood events. Arrows indicate main compositional trends discussed in the text. TIC, TN and TS (expressed as percentages), and C/N ratio are discussed in the text. Lithological unit limits and their age are indicated by dashed lines.

Figure 4. N-S stratigraphic cross-section including the eight cores retrieved from Raraku Lake corresponding to this study (RAR1 to RAR8) and other cores from former studies. Cores are projected as indicated in the figure map. Stratigraphic correlations are based on lithological and sedimentological criteria (limits between units and flood key levels) and magnetic susceptibility profiles.

Figure 5. Selected Raraku Lake facies. Photo A. High gradient lacustrine deposits: Laminated silty mud (Facies 1, Unit 1). Photo B. Low gradient lacustrine deposits: (b1) silty major flood F17 (Facies 2, Subunit 2a,), (b2) varicolored laminated mud (Facies 4, Subunit 2a). Photo C. Low gradient lacustrine deposits: two color laminated mud (Facies 5, Subunit 2a). Photo D. Peatbog deposits: Scirpus dominated peat (Facies 8, Subunit 3a).

Figure 6. Compilation of paleoclimatic south circum Pacific terrestrial and marine records realized for comparisons with Easter Island record and to explain south Pacific climate patterns during the last 34 cal. kyr BP. From the left to the 
right: The insolation curve for $30^{\circ} \mathrm{S}$ and $30^{\circ} \mathrm{N}$ (Berger and Loutre, 1991); the relative Raraku Lake level changes established by (i) the frequency and thickness of floods into the lake, (ii) the occurrence of onlap surfaces in Raraku Lake from this study, and (iii) the diatom presence in some intervals; the evolution of lake productivity is shown by the percentage of TOC and the terrigenous input is indicated by XFR Ti (counts per seconds); the pollen record zones from Flenley et al. (1991) and Azizi and Flenely (2008); (1) Terrestrial pollen record (Newnham et al., 2007), (2) Terrestrial pollen record (McGlone, 2002), (3) Terrestrial pollen record (Markgraf et al., 2007) (4) Terrestrial pollen record (Heusser and Heusser, 2006), (5) Terrestrial pollen record (Moreno and León, 2003), (6) Terrestrial pollen record (Valero-Garcés et al., 2006), (7) Terrestrial pollen record (Maldonado and Villagran, 2006), (8) plant macrofossisls record (Latorre et al., 2006), (9) Lacustrine diatom record \% Plaktonic diatoms, XRF, organic components and MS data (Sáez et al. 2007, Giralt et al., 2008), (10) Terrestrial pollen record (Paduano et al., 2003) and diatoms study (Tapia et al., 2003), (11) Alkenone SST (Kaiser et al. 2006, Lamy et al., 2007), (12) Alkenone SST and plant-wax n-alcanes (Kaiser et al., 2008), (13) Alkenone SST and $\delta^{18} \mathrm{O}$ in planktonic foraminifera (Lea et al., 2006), and (14) $\delta^{18} \mathrm{O}$ in planktonic foraminifera Pena et al. (2008) (location of these sites is indicated in Figure 1).

Table 1. ${ }^{14} \mathrm{C}$ AMS radiocarbon age measured in pollen-enriched extract and Scirpus remains of Raraku Lake core samples. Calibration based on INTCAL98 (Stuiver et al., 1998; Reimer et al., 2004). ${ }^{a}$ Age too young because contamination from roots. ${ }^{\mathrm{b}}$ Age too old because contamination by older material from the lake margins. ${ }^{\mathrm{c}} \mathrm{Calibrated}$ with CalPal (Danzeglocke et al., 2008)

Table 2. Correlation coefficients between analytical variables used in this study. The dataset has 16 variables and 9466 samples (MS = Magnetic Susceptibility). Significant correlations according to the Bonferroni test (see text) are shown in bold. The correlation reveals that $\mathrm{Si}, \mathrm{Fe}, \mathrm{S}$ and Ti XRF elements and the MS have a strong positive relationship with the terrigenous minerals (kaolinite, ilmenite) and partially with pyrite. Negative correlations are found between the terrigenous components and organic indicators (TOC, TN and inc/coh ratio). 


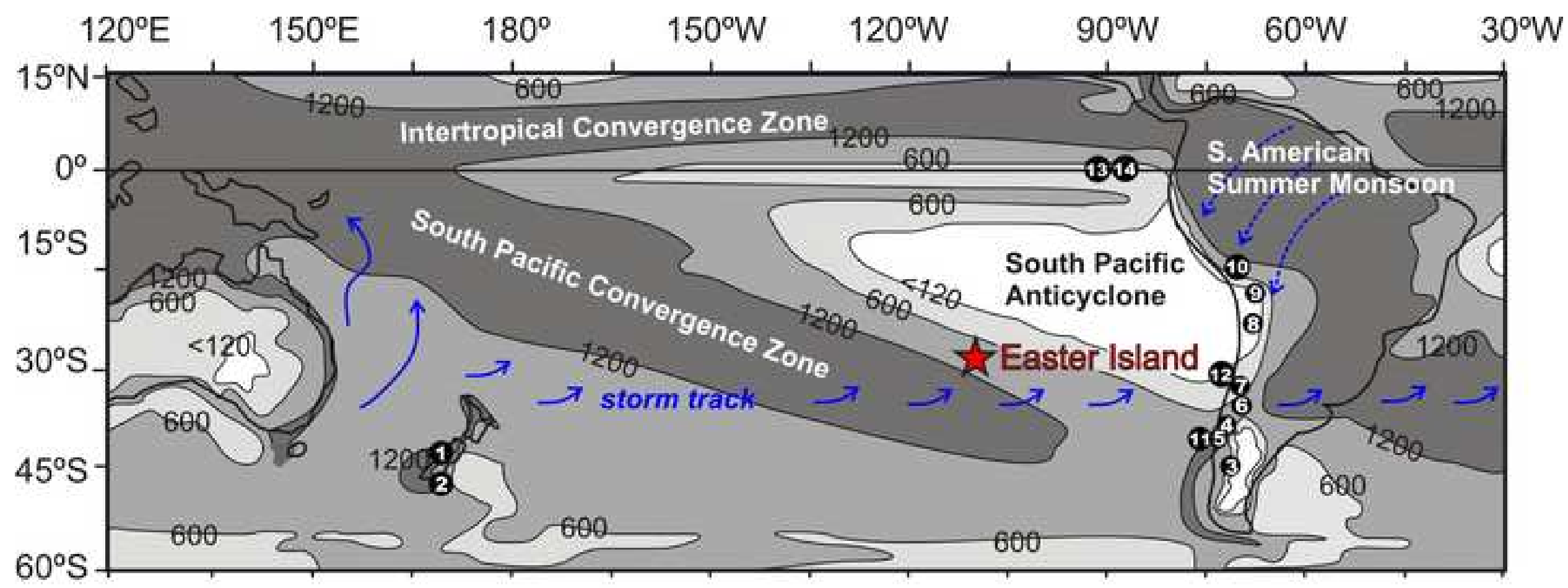

Figure 1 
Figure 2

Click here to download high resolution image

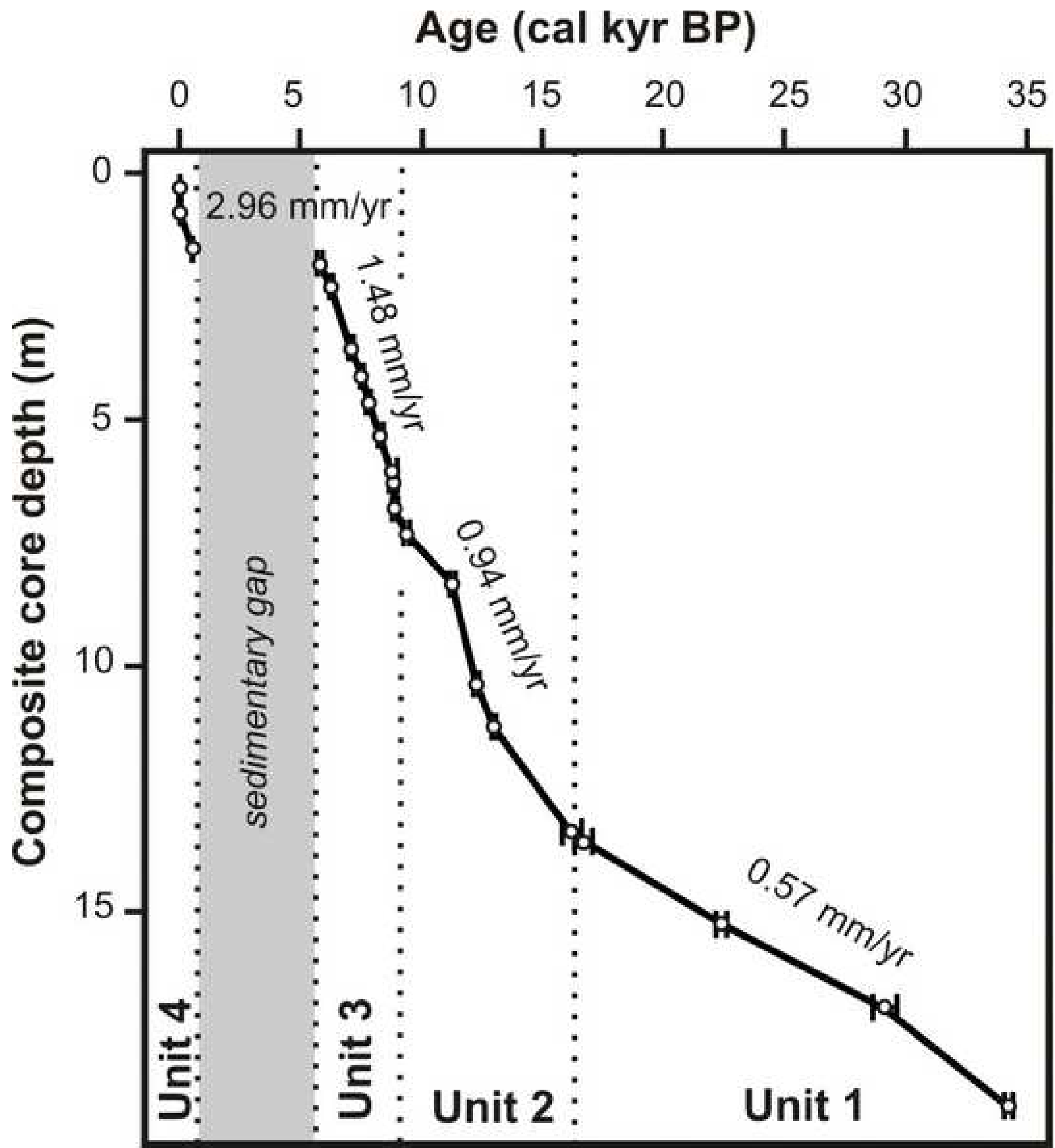

Figure 2 


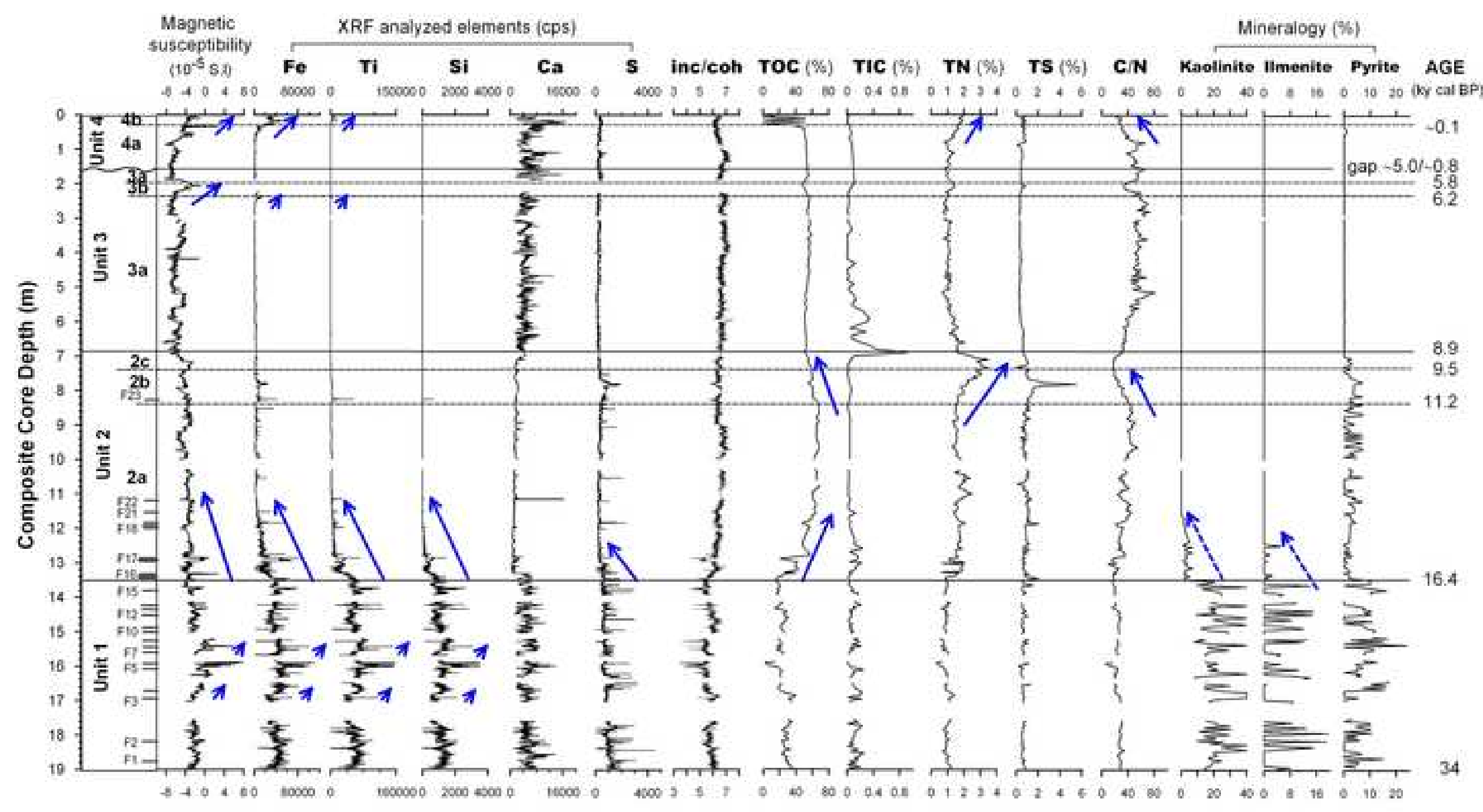

Figure 3 
N-S RAR-01 RAR-02
RAR-03

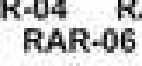

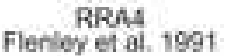

modern
RAR-07 RAR-08

CORE

Dumant et al. 1998 ann et ail. 2009 RRA3

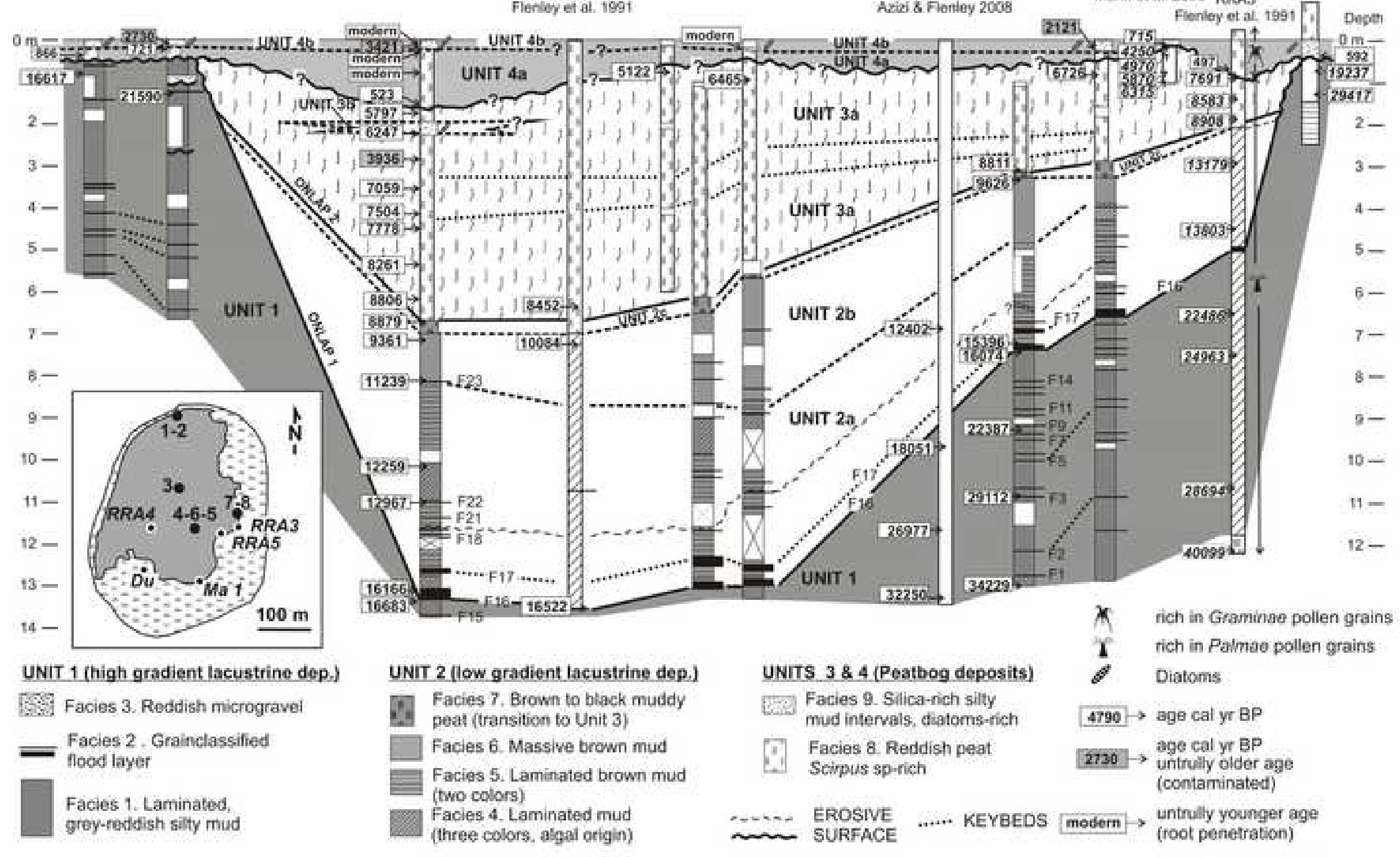


Click here to download high resolution image
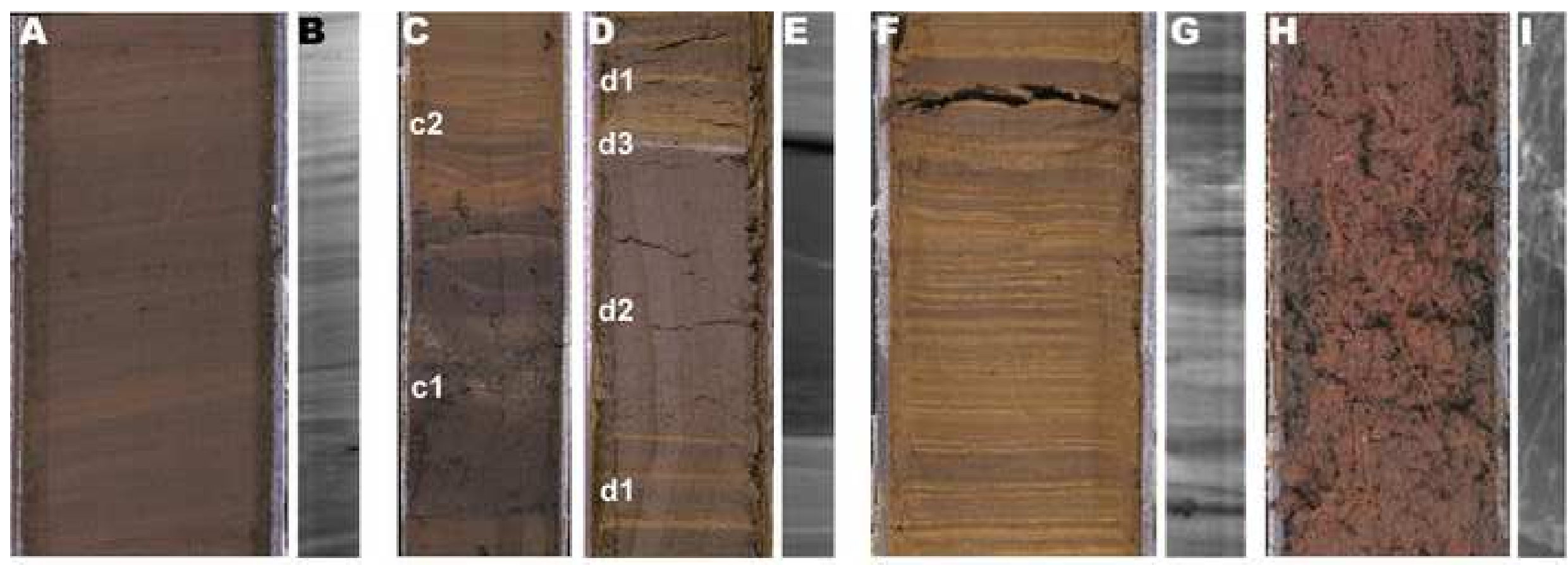

$1 \mathrm{~cm}$ $1 \mathrm{~cm} \mathrm{I} 1 \mathrm{~cm}$

$11 \mathrm{~cm}$

$I_{1} \mathrm{~cm} \mid 1 \mathrm{~cm}$

$I_{1 \mathrm{~cm}} I_{1 \mathrm{~cm}}$

$11 \mathrm{~cm}$

Figure 5 


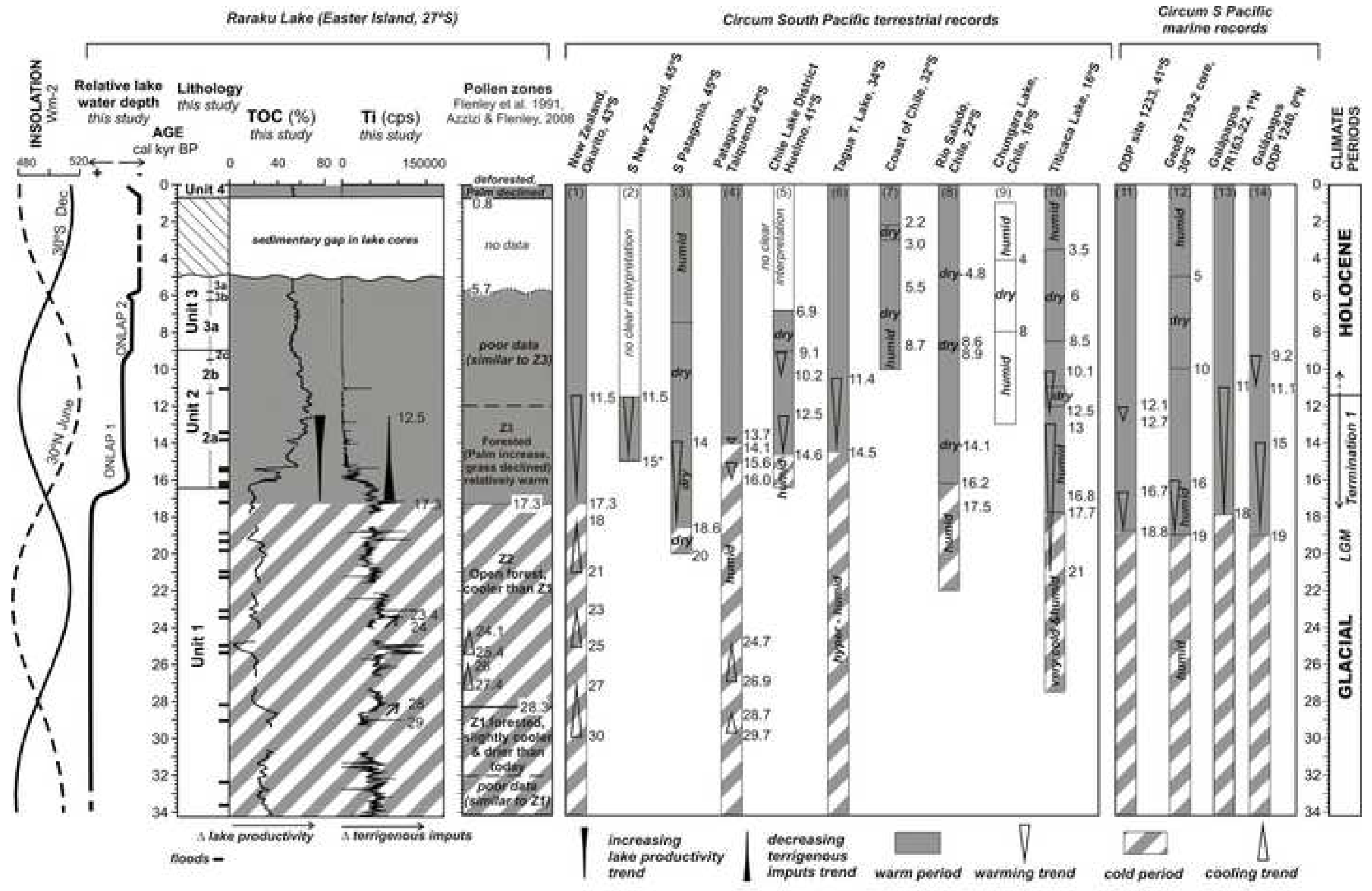

Figure 6 


\begin{tabular}{|c|c|c|c|c|c|c|c|c|}
\hline sample & unit & facies & $\begin{array}{c}\text { Composit } \\
\text { e } \\
\text { depth }(\mathbf{m})\end{array}$ & fraction dated & $\begin{array}{l}{ }^{14} \mathrm{C} \mathrm{yr} \\
\text { BP }\end{array}$ & $+/-$ & $\begin{array}{c}\text { dates } \\
\text { (cal yr } \\
\text { BP) } \\
\end{array}$ & $+/-$ \\
\hline \multicolumn{9}{|c|}{ core RAR03 } \\
\hline Poz-20530 & $4 b$ & facies 9 & 0.17 & Scirpus macrorest & $109^{\mathrm{a}}$ & 0.4 & & \\
\hline Poz-19934 & $4 \mathrm{~b}$ & facies 9 & 0.2 & ollen-enriched extrac & $3205^{\mathrm{b}}$ & 35 & $3421^{\mathrm{b}}$ & 61 \\
\hline Poz-24023 & $4 a$ & facies 8 & 0.3 & Scirpus macrorests & $112^{\mathrm{a}}$ & 0.4 & & \\
\hline Poz-24024 & $4 a$ & facies 8 & 0.8 & Scirpus macrorests & $100^{\mathrm{a}}$ & 0.4 & & \\
\hline Poz-24025 & $4 a$ & facies 8 & 1.55 & Scirpus macrorests & 490 & 35 & 523 & 22 \\
\hline Poz-24026 & $3 a$ & facies 8 & 2.85 & Scirpus macrorests & $3640^{b}$ & 35 & $3936^{\mathrm{b}}$ & 76 \\
\hline Poz-20571 & $3 a$ & facies 8 & 1.85 & Scirp & 5030 & 40 & 5797 & 99 \\
\hline Poz-19935 & $3 a$ & & 2.3 & sollen- & 545 & & 6247 & 62 \\
\hline Poz-24027 & $3 a$ & facies 8 & 3.55 & Scirpus macrorest & 617 & 40 & 7059 & 110 \\
\hline Poz-24030 & $3 a$ & & 4.14 & & 662 & & 7504 & 70 \\
\hline Poz-18689 & $3 a$ & s 8 & 4.65 & enriched extrac & 6960 & 40 & 7778 & 88 \\
\hline Poz-24031 & $3 a$ & & 5.34 & us macrorests & 7410 & & 8261 & 103 \\
\hline Poz-24032 & $3 a$ & s 8 & 6.15 & Scir & 793 & & 8806 & 178 \\
\hline Poz-18690 & $2 \mathrm{c}$ & & 6.83 & sollen & & & 8879 & 132 \\
\hline Poz-18691 & $2 b$ & & 7.3 & solle & 834 & & 936 & 120 \\
\hline Poz-19936 & $2 b$ & & & solle & 98 & & 112 & 115 \\
\hline Poz-1 & $2 \mathrm{a}$ & & 10.3 & solle & 104 & & 122 & 155 \\
\hline Poz-18694 & $2 \mathrm{a}$ & & 11.2 & soller & $110^{2}$ & 5 & 129 & 96 \\
\hline Poz-18696 & $2 \mathrm{a}$ & & 13.39 & soller & 135 & 70 & 1616 & 406 \\
\hline \multicolumn{9}{|c|}{ core RAR07 } \\
\hline Poz-18700 & $3 a$ & & & polle & 794 & 50 & 81 & 178 \\
\hline Poz-18701 & $2 b$ & & & poller & 868 & & 9626 & 84 \\
\hline Poz-18703 & $2 \mathrm{a}$ & & 13.08 & soller & 1301 & & 153 & 312 \\
\hline Poz-18704 & 1 & & & extrac & 135 & 0 & & 382 \\
\hline Poz-19938 & 1 & & 15.27 & sollen-enriched extrac & 18850 & 130 & 223 & 236 \\
\hline Poz-19939 & 1 & facies 1 & 16.95 & sollen-enriched extrac & 24340 & 230 & $29112^{\mathrm{c}}$ & 484 \\
\hline $\begin{array}{l}\text { Poz-18705 } \\
\text { core RAR0 }\end{array}$ & 1 & facies 1 & 18.97 & sollen-enriched extrac & 30060 & 240 & $34229^{c}$ & 192 \\
\hline Poz-19930 & $4 a$ & facies 8 & 0.37 & & 975 & & & 71 \\
\hline $\begin{array}{l}\text { Poz-18688 } \\
\text { core RAR0 }\end{array}$ & $2^{1}$ & facies 1 & & pollen-enriched extrac & 13950 & 70 & 16617 & 390 \\
\hline Poz-19931 & $4 b$ & facies 9 & & pollen & $2580^{\mathrm{b}}$ & 40 & $2730^{\mathrm{b}}$ & 39 \\
\hline Poz-19933 & $4 a$ & facies 8 & 0.25 & sollen & 795 & 35 & 721 & 49 \\
\hline $\begin{array}{l}\text { Poz-18743 } \\
\text { core RAR0 }\end{array}$ & $4^{1}$ & facies 1 & & pollen-enriched extrac & 18180 & 120 & 21590 & 473 \\
\hline $\begin{array}{l}\text { Poz-18697 } \\
\text { core RAR0 }\end{array}$ & & facies 8 & & pollen-enriched extrac & 4535 & 35 & 5122 & 71 \\
\hline Poz-19937 & $4 a$ & & & pollen-enriched extrac & $103^{\mathrm{a}}$ & 0.4 & & \\
\hline $\begin{array}{l}\text { Poz-18699 } \\
\text { core RAR08 }\end{array}$ & $8^{3 a}$ & facies 8 & & pollen-enriched extrac & 5660 & 40 & 6465 & 77 \\
\hline Poz-19940 & $4 \mathrm{~b}$ & facies 9 & & pollen-enriched extrac & $2160^{b}$ & 30 & $2121^{b}$ & 65 \\
\hline Poz-18706 & $3 a$ & facies 8 & & pollen-enriched extrac & 5910 & 40 & 6726 & 75 \\
\hline
\end{tabular}

Table 1 
Sheet1

\begin{tabular}{|c|c|c|c|c|c|c|c|c|c|c|c|c|c|c|c|c|}
\hline & MS & TS & TIC & TOC & TN & $\mathbf{S i}$ & $\mathbf{S}$ & $\mathrm{Ca}$ & $\mathrm{Ti}$ & $\mathrm{Fe}$ & inc.coh & raolin. & felsp. & Quartz & Pyrit. & Ilmen. \\
\hline MS & 1 & & & & & & & & & & & & & & & \\
\hline TS & 0.38 & 1 & & & & & & & & & & & & & & \\
\hline TIC & 0.18 & -0.08 & 1 & & & & & & & & & & & & & \\
\hline TOC & -0.51 & 0.15 & -0.48 & 1 & & & & & & & & & & & & \\
\hline TN & -0.14 & 0.57 & -0.2 & 0.52 & 1 & & & & & & & & & & & \\
\hline Si & 0.73 & 0.09 & 0.42 & -0.79 & -0.49 & 1 & & & & & & & & & & \\
\hline $\mathbf{S}$ & 0.64 & 0.34 & 0.17 & -0.43 & -0.16 & 0.69 & 1 & & & & & & & & & \\
\hline $\mathrm{Ca}$ & -0.02 & -0.51 & 0.2 & -0.44 & -0.56 & 0.23 & 0.19 & 1 & & & & & & & & \\
\hline $\mathrm{Ti}$ & 0.82 & 0.41 & 0.25 & -0.56 & -0.2 & 0.88 & 0.75 & -0.05 & 1 & & & & & & & \\
\hline $\mathrm{Fe}$ & 0.78 & 0.36 & 0.33 & -0.67 & -0.18 & 0.84 & 0.72 & 0.09 & 0.9 & 1 & & & & & & \\
\hline inc.coh & -0.73 & -0.31 & -0.32 & 0.65 & 0.25 & -0.79 & -0.66 & -0.11 & -0.77 & -0.82 & 1 & & & & & \\
\hline Kaolinite & 0.71 & 0.12 & 0.4 & -0.76 & -0.44 & 0.95 & 0.65 & 0.16 & 0.86 & 0.82 & -0.76 & 1 & & & & \\
\hline Felspars & 0.39 & 0.19 & 0.06 & -0.25 & -0.04 & 0.42 & 0.34 & -0.12 & 0.46 & 0.41 & -0.36 & 0.36 & 1 & & & \\
\hline Quartz & 0 & 0.02 & -0.02 & -0.19 & -0.15 & 0.15 & 0.08 & 0.01 & 0.09 & 0.11 & -0.12 & 0.17 & 0.1 & 1 & & \\
\hline Pyrite & 0.61 & 0.49 & 0.09 & -0.27 & -0.11 & 0.55 & 0.57 & -0.15 & 0.71 & 0.61 & -0.56 & 0.53 & 0.33 & 0.06 & 1 & 1 \\
\hline Ilmenite & 0.45 & 0.12 & 0.17 & -0.53 & -0.35 & 0.61 & 0.45 & 0.08 & 0.54 & 0.53 & -0.55 & 0.59 & 0.3 & 0.26 & 0.37 & \\
\hline
\end{tabular}

